Financing Decisions in Family Businesses: A Review and Suggestions for Developing the Field

Peer-reviewed author version

MICHIELS, Anneleen \& Molly, Vincent (2017) Financing Decisions in Family Businesses: A Review and Suggestions for Developing the Field. In: Family Business Review, 30 (4), p. 369-399.

DOI: $10.1177 / 0894486517736958$

Handle: http://hdl.handle.net/1942/25168 


\title{
Financing Decisions in Family Businesses: A Review and Suggestions for Developing the Field
}

\author{
Anneleen Michiels, Vincent Molly \\ Appeared in: Family Business Review, 2017, Vol 30, Issue 4
}

\begin{abstract}
Motivated by the growing attention to the financing decisions of family firms, this review brings together the two highly-relevant research fields of family business and finance. This study critically reviews 131 articles on financing decisions in family businesses, published between 1977 and 2016 in 64 finance and management journals. We develop a state of the art on family business financing literature and present a model to guide extant and future research by identifying gaps across the theoretical perspectives and across context-specific elements such as family business heterogeneity and country-specific factors.
\end{abstract}

Keywords: family business, literature review, financing decisions

\section{INTRODUCTION}

In their seminal work, Modigliani and Miller (1958) declared financing decisions to be irrelevant in a perfect capital market. Discussing and challenging their basic assumption of a perfect capital market, many researchers have shown that, in the real world, financing decisions matter (e.g., Stiglitz, 1969, 1974; Fama, 1978; Myers, 1984; Myers \& Majluf, 1984). In family firms, these decisions may be more relevant for both practical and theoretical reasons. Practically, the importance given to family business financing decisions has been demonstrated through EU policies that consider access to finance as one of the main challenges of family firms (European Commission, 2015). Benavides-Velasco et al. (2013) along with Voordeckers, Le Breton-Miller and Miller (2014) have highlighted the theoretical importance, showing that finance is not only one of the top areas in family business research but also a growing area. This attention, both practically and theoretically, is warranted, since the availability of sufficient 
financial resources is of critical importance for the family firm's survival and growth (Koropp et al., 2014). Financing, for example, has been linked to strategic decisions such as the timing of succession (Kimhi, 1997), the sale of the family business (Bhattacharya \& Ravikumar, 2001), and the internationalization of the family firm (Benito-Hernandez, Priede-Bergamini \& LópezCózar-Navarro, 2014). Overall, the above makes clear the significance of this topic for family firms and that more research is needed in this direction.

An understanding of financing decisions is clearly of great importance for family firms and scholars as this is considered along with the 'peculiar financial logic' that characterizes family firms (Gallo et al., 2004). Specifically, a review of the literature shows that several inconsistencies can be found and that various factors complicate a thorough understanding of family business financing decisions. Therefore, our aim in this article is to analyze and systematize prior work on financing decisions in family firms which will help identify (theoretical) shortcomings and present a framework for organizing (future) research in this field. We focus in this review on articles dealing with "all" types of family businesses, meaning that they can be characterized by family involvement in various ways, and can be private or public firms, small or large firms. Given the dispersed nature of the family business financing literature and the gap that still exists between the family business and finance field of research, we believe a thorough review can bring a large contribution to both disciplines and will form a good basis to elaborate future studies on finance in family businesses.

To the best of our knowledge, this is the first study that gives a state of the art on family business financing literature. Based on a comprehensive literature review we synthesize existing evidence on financing decisions in family businesses and present a framework for organizing and better understanding extant and future research on financing decisions in family firms. It structures current theoretical thinking and sets a research agenda for the future, containing several suggestions on theoretical integration, sampling and study design. This way, 
we articulate and spotlight areas where family business scholars may most fruitfully direct their attention, which will in turn advance our knowledge of financing decisions in family businesses.

\section{METHOD AND SAMPLE}

\section{Review Method}

In this article, we follow the systematic review method of David and Han (2004), which is explicit in its selection of studies and employs quantitative methods of evaluation. First, we searched for journal articles published in peer-reviewed journals until December 31, 2016, written in English language, thereby excluding book chapters or unpublished work. Second, we oriented our search toward the following two databases which cover major journals in the area of finance and business/management: Business Source Premier and Academic Search Elite. Third, in order to find relevant articles, we looked for the combination of a finance entity and a family business entity in the title and/or the abstract (Salvato \& Moores, 2010; Pukall \& Calabro, 2014). With respect to the latter, we focus on articles dealing with companies that are characterized by family involvement in various ways. This is also visible from the choice of our search keywords being used in the search engine: ((financ*) OR (debt) OR (equity) OR (stock) OR (capital) OR (leverag*) OR (IPO) OR (bank*) OR (investor*) OR (dividend*) OR (borrow*) OR (lend*) OR (loan*) OR (credit) OR (collateral)) AND (("family firm*") OR ("family business *") OR ("family enterprise*") OR ("family influenc*") OR ("family control*") OR ("family owner*") OR ("family manag*") OR (family govern*) OR ("founding family")).

An article had to provide conceptual advancements in the understanding of financing decisions in family firms or empirically test propositions regarding financing decisions within a family business context. Therefore, in a fourth step, the relevance was checked by reading all the abstracts. The remaining articles were read completely in order to ensure substantive relevance for this study. Finally, to ensure that no relevant article was missed, additionally the major outlets for family business research were scanned individually. They were selected from 
previous literature reviews in the field (Kontinen \& Ojala, 2010; Zahra \& Sharma, 2004; Pukall \& Calabro, 2014, Siebels \& zu Knyphausen-Aufseß, 2012). We manually checked the indexes of Family Business Review, Journal of Business Venturing, Entrepreneurship: Theory and Practice, and Journal of Small Business Management. Additionally, we checked for studies in Journal of Family Business Strategy, which first appeared in 2010. Using the method and criteria described, a total of 868 manuscripts were identified and evaluated with 131 articles retained for review.

In a next phase, both authors independently screened the articles following a predefined coding scheme. In case of disagreement, a third family business scholar was asked to code the concerning article, after which a common understanding was reached. The following aspects were considered as important in analyzing the content of the articles: (1) focal topic area; (2) theoretical approaches (theories used, family business definition used); (3) methods (country of research, sample size, data source, period of research, quantitative or qualitative, analytical approach, temporal dimension, public or private or both, family versus nonfamily or within family); (4) main findings; (5) journal in which the article was published.

The review of these 131 papers was supplemented with data collected from an expert panel, consisting of prominent scholars in the family business field. The use of an expert panel can be considered as a qualitative way to explore and identify key themes in the literature and thus to provide additional insights (Jones \& Gatrell, 2014). Additionally, this approach allows us to integrate the most recent thoughts on family business financing, and thus reduces the potential limitation of publication time lag in some scholarly journals. We emailed all associate editors of the two SSCI-ranked family business journals (Family Business Review and Journal of Family Business Strategy), together with some prominent family business and/or finance scholars. In total, nine scholars cooperated and provided us with valuable additional insights. We provided them with three questions on promising research topics, promising theoretical 
frameworks, and other suggestions on finance for family business scholars. We first interpreted the answers to these questions for each scholar individually, followed by a comparison of the insights from all the scholars to find the most relevant suggestions.

\section{General Sample Characteristics}

The articles on financing decisions in family firms accepted for the analysis are published in a wide variety of management/business, finance and economics journals, and have taken a rapid growth after the year 2000, especially in the management/business and the finance field. Appendix A contains a detailed description of the distribution of the sample across journals and their impact factor.

Our review further indicates that most studies on financing decisions in family firms are based on European data, followed by Asia and North America, while analyses on South American, African or Australian samples are rare. $81 \%$ of the studies focus on one single country, while in $19 \%$ of the articles data on multiple countries are included. Table 1 gives an overview of the most important methodological parameters of the selected articles.

\section{Insert Table 1 Here}

The majority of studies applied regression techniques, followed by categorical dependent variable analyses (logit, probit, tobit). The data mainly comes from (public) databases and in only 21 out of 131 articles, analyses are based on survey information. Qualitative studies based on interviews or case studies are quite exceptional. Most of the studies are oriented towards public family firms. The dominance of samples of public family firms might be explained by the widespread reliance on commercial databases and other secondary data sources. About $70 \%$ of the articles includes the criteria on how to identify family firms, 
meaning that almost one out of three studies lacks a clear family business definition. Finally, two thirds of the studies in our sample makes the traditional comparison between family and non-family businesses without taking into account family business heterogeneity. When further examining this subsample of articles, we find no differences with regard to type of journal or date of publishing. Yet, papers that ignore family business heterogeneity use public databases more often as compared to the full sample of articles and make less use of survey data. Thus, although numerous scholars have stressed the importance to acknowledge the heterogeneity of family businesses, data limitations might be one explanation as to why the minority of financing studies actually takes this heterogeneity into account.

More than $40 \%$ of the articles in our sample discuss issues concerning debt decisions (e.g., leverage, debt maturity or target debt rate). Decisions regarding equity (e.g., buyouts, private equity, venture capital or IPOs) are discussed in $34 \%$ of the articles. Decisions related to retained earnings (e.g., dividend payout) are examined in $22 \%$ of the articles. Finally, other alternative financing decisions such as leasing, factoring or crowdfunding are discussed in about $2 \%$ of the papers.

When looking at the applied theoretical framework, we see a clear dominance of agency theory. In about half of the articles agency theoretical arguments are used for developing the hypotheses and explaining the results. Pecking order theory and the socioemotional wealth perspective (SEW) close the ranks in the top 3 of most frequently used theories. It is also remarkable that in almost one out of five articles no theoretical arguments are specified. When further investigating the characteristics of the articles that are not using a clear theoretical framework, we find that they are published in finance journals more often than in our full sample of articles. Articles without a theoretical framework are also generally older than studies that have a (partial) theoretical foundation. 


\section{WHERE ARE WE NOW?}

\section{Theoretical Foundations}

Our survey of the literature on financing decisions in family firms shows that several traditional capital structure theories have been used. As described by Titman and Wessels (1988), Harris and Raviv (1991), Fama and French (2002), and Frank and Goyal (2003), most capital structure theories start from the trade-off or pecking order approach. Both of which are inspired by agency theory (Jensen \& Meckling, 1976). Agency theory points to the information asymmetries and conflicts of interests between shareholders and bondholders, between shareholders and managers (principal-agent), and among shareholders (principal-principal). Trade-off theory (Modigliani \& Miller, 1958; Myers, 1989) focuses on costs resulting from information asymmetries between shareholders and bondholders and on benefits such as a reduction of the free cash flow agency costs (principal-agent) resulting from the use of debt. Next to that, potential bankruptcy costs and deductibility of interest payments are considered to trade-off the costs and benefits related to debt financing to determine the optimal capital structure in a company. An alternative capital structure theory, known as the pecking order model, has been developed by Myers (1984). This model is based on information asymmetries between the firm and the capital supplier. As transaction costs arise for each new issue of securities or debt, firms will prefer to finance their investments first with retained earnings, then with debt, and finally with equity. In this way, the financing choice is driven by the firm's desire to minimize information asymmetry costs in raising external finance.

In addition to these traditional theoretical frameworks that mainly focus on the optimization of the firm's capital structure to maximize firm value, the literature gives evidence of non-traditional approaches to financing decisions in family firms. For example, Barton and Matthews (1989), Hutchinson (1995), and Romano, Tanewski and Smyrnios (2001) take into 
account owner/manager preferences for understanding the capital structure of these firms. They point to the importance of control retention, risk aversion and non-financial values and goals in the owners'/managers' financial decision-making. This usually results in a higher preference for internally generated funds rather than external sources, or debt financing rather than external equity funding. Recently, these approaches and arguments have been linked to theoretical frameworks such as the stewardship theory (Davis et al., 1997), the socioemotional wealth (SEW) perspective (Gomèz-Meija et al., 2007) and the theory of planned behavior (Ajzen, 1991). Stewardship theory starts from the idea that individuals in a company are not predominantly self-serving, but that their motives support those of the company and go beyond purely economic goals (Zahra et al., 2008). As opposed to agency theory, which focuses on extrinsic motivation of individuals serving themselves, stewardship theory stresses their intrinsic motivation. The SEW perspective is rooted within the behavioral agency model (Wiseman \& Gomez-Mejia, 1998) and refers to the firm's non-financial aspects that meet the family's affective needs, such as identity, exercising family influence and perpetuating the family dynasty (Gomèz-Meija et al., 2007). According to this perspective, family firms are expected to pay significant attention to maintaining family control and are loss averse when their SEW is threatened. Finally, the theory of planned behavior considers the family's attitudes and values, preferences and norms, and behavioral control as determining factors of behavioral intentions, which eventually influence behavioral decisions and choices (Koropp et al., 2014).

\section{What Do We Know About Financing Decisions in Family Firms?}

In this section, we discuss family business financing studies in detail, by categorizing them into three groups, based on the source of financing they deal with.

\section{Debt}


When family businesses consider using external sources of financing, leverage remains by far the most preferred funding option for family firms (Poutziouris, 2001; Romano, Tanewski, \& Smyrnios 2001; Croci, Doukas \& Gonenc, 2011; Koropp et al., 2013; Burgstaller \& Wagner, 2015). As indicated by Blanco-Mazagatos, Ouevedo-Puente and Castrillo (2007), research findings give evidence of a pecking order in financing family firms, where debt instead of new equity is preferred when additional external financing is sought. However, other studies find evidence of a negative effect of family ownership on the use of debt financing in both private (Gallo \& Vilaseca, 1996) and public (Mishra \& McConaughy, 1999) family firms. This negative relation is explained by the dominance of control risk motivations, the fear of bankruptcy costs and the bank's credit underwriting policy which concentrates on owners' wealth instead of the repayment capability of the family firm (Gallo \& Vilaseca, 1996; Mishra \& McConaughy, 1999). An interesting phenomenon that has further been linked to the lower leverage in many family businesses, concerns the zero-leverage company, which tend to occur more often in family than in non-family firms, explained by a stronger aversion in family firms to the risks linked to financial distress (Strebulaev \& Yang, 2013). Finally, studies of Coleman and Carsky (1999) and Bjuggren, Duggal and Giang (2012), both focusing on privately-held firms, contradict the above findings, as they were not able to find significant differences in the level of debt used by family versus non-family firms.

This overview shows that the literature still remains inconclusive on the level of debt used in family firms. This is no surprise, since, according to Gonzalez et al. (2013), Schmid (2013) and Burgstaller and Wagner (2015), a trade-off needs to be made in family firms between retention of control, which favors the use of debt financing over external equity, and risk-aversion, which stimulates the company to adopt more cautious attitudes toward debt. These non-traditional, behavioral aspects illustrate the complexity of the leverage decision in family firms. Another factor that further complicates the debt choice analysis concerns the wide 
array of leverage alternatives. Although most studies focus on the total debt rate, the work of Chagantie and Damanpour (1991), Al-Ajmi et al. (2009), Mishra and McConaughy (1999), Shyu and Lee (2009), Croci et al. (2011), Poutziouris (2011), and Segura and Formigoni (2014) considers the distinction between short- and long-term debt financing, where findings are mainly explained through agency, pecking order, and trade-off theory. Since information asymmetry and transaction costs differ according to the debt maturity structure, this complicates the comparison between studies and the search for consistent results.

Furthermore, most studies in our literature review focus on the comparison between family and non-family businesses. In almost two out of three studies that were reviewed, a comparison is explicitly made between these two types of organization. The heterogeneity among family businesses is therefore often neglected. However, the differences within the group of family firms may potentially be even larger than the differences between family and nonfamily firms (Chua, Chrisman, Steier \& Rau, 2012) and researchers have therefore called to focus on the heterogenous nature of family businesses (Chua et al., 2012; Nordqvist, Sharma \& Chirico, 2014). Some studies on capital structure do take this into consideration by integrating the family's role in management (Schmid, 2013), the difference between ownermanaged and non-owner-managed companies (Batten \& Hettihewa, 1999), or the presence of independent outside directors in the governance of the firm (Napoli, 2012). It is clear that these differences in the management, ownership and governance structure can influence the relationship and information asymmetries between shareholders and bondholders. Other authors consider family ownership by focusing on the distinction between cash-flow and control rights, and the presence of principal-principal agency problems, and how this influences the family firm's leverage (King \& Santor, 2008; Shyu \& Lee, 2009). Also Bjuggren et al. (2012) focus on ownership and find evidence of a $u$-shaped relation between ownership dispersion and debt in private family businesses, which confirms the earlier work on private family firms of 
Schulze, Lubatkin and Dino (2003). Schulze et al. (2003) found evidence that the risk-attitude of private family firms changes due to the ownership dispersion in family businesses. Especially sibling partnerships were found to use less debt, and thus willing to bear less risk, compared to controlling owners and cousin consortiums, since they are characterized by increased levels of loss aversion and misalignment among family members.

A number of authors further stress the importance of the generational effect on a family firm's capital structure. While most of these studies exclusively focus on privately-held firms (Molly et al., 2010, 2012; Blanco-Mazagatos et al., 2007; Burgstaller \& Wagner, 2015; Koropp et al., 2013b), others include both public and private firms in their sample (Gonzalez et al. 2013; Amore et al., 2011). Findings indicate that family generation negatively impacts debt financing (Molly, Laveren \& Deloof, 2010; Molly, Laveren \& Jorissen 2012), while Blanco-Mazagatos et al. (2007) and Gonzalez et al. (2013) come to the opposite conclusion. Burgstaller and Wagner (2015) were not able to confirm a generational effect on the use of debt in the family firm. Finally, Koropp et al. (2013b) and Amore et al. (2011) investigate the impact of succession on the firm's financing policies, where the latter study for example finds that non-family CEOs stimulate the use of leverage. It is also important to stress that inconsistent findings can partly result from the focus in different studies either on behavioral aspects (retention of control and risk aversion), or on agency theoretical aspects (free cash flow problems and shareholderbondholder agency problems), or on both. In addition, some studies only indirectly measure a generation effect through the firm's age, or only make a comparison between founders and descendants without discerning between first-, second- or later-generation family firms.

Where most of the studies on debt policy in family businesses take into account the demand side of financing, other studies mainly focus on the banks' point of view and the applied debt conditions towards family businesses (supply side). Overall, these studies find that banks generally have a positive feeling towards family businesses, reducing potential shareholder- 
bondholder agency problems. They are considered to be better borrowers with less moral hazard problems (Bopaiah, 1998). This higher trust of banks in family firms results in easier access to credit in general (Bopaiah, 1998), and more long term debt in particular (Croci et al., 2011). In addition, the easier access to debt financing enables family firms to adjust faster toward their target leverage (Pindado et al., 2015). With respect to this, Song and Wang (2013) focus on the importance of the relational strength between the family firm and the financial institution in order to lower information asymmetries. Chua, Chrisman and Kellermans (2011) even bring forward the relevance of borrowing social capital (relying on relationships to get access to resources) available in the family to improve access to bank financing in new family ventures. Other findings indicate that several aspects, such as the presence of pyramid structures (Masulis, Pham \& Zein, 2011) lower the financing constraints imposed by banks on family firms. Finally, Chen, Ding, Wu and Yang (2016), find that family firms benefit less from the adoption of IAS (International Accounting Standards) than nonfamily firms in terms of access to foreign banks.

When turning to the cost of debt financing, Anderson, Mansi and Reeb (2003) also focus on the owner-debtholder agency problem to analyze debt financing in publicly-listed US family firms. They find evidence that the cost of debt is lower in firms with family ownership, external CEOs or family CEOs who belong to the founding generation. Also Boubakri and Ghouma (2010) focus on the information asymmetries between shareholders and bondholders in public firms, but they come to an opposite conclusion in their European and Asian sample. Because bondholders fear the expropriation by controlling shareholders, family control is found to increase the cost of debt funding. Similarly, Tanaka (2014) finds that bondholders of listed Japanese firms are concerned about family agency conflicts, with an increasing effect on the cost of public debt as a result. The findings of Yen et al. (2015) can be linked to these previous studies, as they conclude that public family firms enjoy more favorable loan contracts than 
nonfamily firms, but that this positive effect diminishes when they are more likely to expropriate external investors. Finally, Waisman (2013) further examines the effect of family ownership and the takeover friendliness of a country, on the pricing of loans in US listed firms.

A limited number of studies deepen the understanding of the shareholder-bondholder agency relationship by taking collateral or guarantees into consideration. Bagnoli et al. (2011) find that listed family firms use financial covenants more intensively than non-family firms. Steijvers and Voordeckers (2009) and Steijvers, Voordeckers and Vanhoof (2010) further point to the use of personal collateral to reduce agency problems in private family firms. Similarly, Voordeckers and Steijvers (2006) present several determinants of collateral protection such as bank competition, the use of credit, the length of the relationship between the bank and the borrower, next to various other factors. In line with these studies, Schmid (2013) finds evidence that the level of debt used in family firms depends on the level of credit monitoring and is different whether they are located in bank-based versus other economies.

Finally, a number of studies focus on alternative forms of debt financing. Di Giuili, Caselli and Gatti (2011), Fitó, Moya and Orgaz (2013) and Landry, Fortin and Callimaci (2013) stress to investigate also other financial instruments used by SMEs such as leasing or factoring. Evidence is found that family firms are less eager to use leasing (Landry et al., 2013), and that the level of financial sophistication (making use of non-basic financial products such as leasing) increases over generations and when the family firm is characterized by an external CFO or external shareholder (Di Giuili et al., 2011). Other studies point to the intertwinement of household and business financing (Haynes, Walker, Rowe \& Hong, 1999; Yilmazer \& Schrank, 2006; Muske et al., 2009), or investigate the use of informal financing coming from friends and family of the owner-manager (Coleman \& Carsky, 1999). The studies indicate that family firms do not significantly differ from nonfamily firms in their use of informal sources of financing (such as loans from family and friends) or financial intermingling (Coleman \& Carsky, 1999; 
Yilmazer \& Schrank, 2006), and that the level of intermingling can be linked to the fact whether the business is incorporated or a sole proprietorship (Haynes et al., 1999), or wether the family business is operated by copreneurs (Muske et al., 2009). Finally, Lappalainen and Niskanen (2013) and Psillaki and Eleftheriou (2015) specifically focus on trade credit, a type of nonfinancial leverage, which is extensively used in many privately-held family firms in practice as well. Lappalainen and Niskanen (2013) focus on the use and attitude towards trade credit in family and nonfamily SMEs, while Psillaki and Eleftheriou (2015) rather investigate the relation and complementarity between bank borrowing and trade credit.

\section{External Equity}

Another stream of research focuses on the use of external equity. On the one hand, several studies indicate that family involvement appears to result in lower use of external equity (Wu et al., 2007; Poutizouris, 2011), both based on samples consisting of private as well as public firms. Usually the distance between family firms and outside investors is quite large, mainly due to the so-called empathy gap between owners and investors (Poutziouris, 2011) or because of the generally preferred retention of control rather than the firm's growth and development (Wu et al., 2007). On the other hand, contrary to the pecking order perspective, King and Peng (2013) find that in industries characterized by cyclicality, capital intensity, and growth, large listed family firms rely on equity financing before debt financing to fund their expansion, mainly because of a strong aversion linked to financial distress.

When further analyzing the literature on external equity in family firms, a number of studies focus on the use of private equity and venture capital. These sources may be more preferred than generally thought because of the opportunities it offers to fund the family firm transition (Upton \& Petty, 2000), or because of the non-financial benefits that such investors can bring to the family such as managerial support, expertise and contacts (Tappeiner et al., 2012; Marti et al, 2013). Other studies investigate the impact of private equity investors on the 
long-term performance (Viviani, Giogino \& Steri, 2008, Desbrières \& Schatt, 2002), the governance structure and its benefits and costs (Achleitner et al., 2010) and the strategy (Scholes et al., 2009) of the family business. Evidence is found that the participation of private equity reduces performance in the years after an IPO (Viviani et al., 2008) or after a leveraged buy-out (Desbrières \& Schatt, 2002). With regard to strategy, Scholes et al. (2009) come to the conclusion that private equity backed buy-outs strongly impact the strategy of family firms, but that this impact varies according to the presence of the founder, the presence of managers with equity stakes, the involvement of non-executive directors, and the involvement in succession planning. Finally, while most studies take the perspective of the family business (demand side), a number of recent studies focus on the perceptions of private equity investors (Dawson, 2011) or institutional investors (Fernando, Schneible \& Suh, 2014) towards family businesses (supply side). Dawson (2011) finds that private equity investors take into account human resources, the level of professionalization and the opportunity to reduce agency costs when selecting family firms. Fernando et al. (2014) bring forward that institutional investors avoid to invest in family firms because of increased type 2 agency problems compared to nonfamily firms.

Firms can also acquire equity financing through an initial public offering (IPO). Our sample contains several papers on this topic, all published after the year 2000. While this is an important event for all kinds of firms, it especially is for family businesses. After all, a change in ownership structure by going public implies a significant change in the governance of family businesses, because it is often the first time that outside shareholders come into play (Ehrardt and Nowak, 2003). The most important financial reason for family businesses to go public, is the need to raise higher funds to finance growth or to rebalance the debt-equity level (Mazzola and Marchisio, 2002). Research on the IPO process can be divided into three categories: the pre-IPO process, the IPO itself (first trading day), and the post-IPO process. As the aim of this 
article is to review studies on the financing decision in family firms, we only examine studies on the pre-IPO process and the IPO itself, and not the performance after an IPO (post-IPO).

The first stream of research indicates that outside expertise in the pre-IPO process appears to be advantageous for family-controlled firms. Family firms may thus benefit from associations with venture capitalists (Astrachan \& McConaughy, 2001) and with prestigious investment banking firms (Walker, 2008) as this lowers the information asymmetries between the issuer and the investors. The second stream of research investigates the initial public offering itself, and more in particular the relation between the closing price and the offer price (IPO over- or underpricing). Family firms are found to have 10 percentage points more IPO underpricing than nonfamily firms (Leitterstorf \& Rau, 2014). A number of studies have further investigated this phenomenon of family business IPO underpricing. IPO underpricing is found to be positively related to family ownership (Lin \& Chuang, 2011), generational stage (Yu \& Zheng, 2012), participation of family members at board level (Hearn, 2011), and the willingness to preserve their SEW (Leitterstorf \& Rau, 2014). IPO underpricing is found to be negatively related to the ratio of nonfamily directors (Ding \& Pukthuangthong-Le, 2009), to wider dispersion of family ownership (Hearn, 2011), and to associations with prestigious investment banking firms (Walker, 2008). These findings indicate that family firms tend to use IPO underpricing as a way of retaining control of the family firm. Alternatively, family firms' IPO underpricing might be a sign of risk aversion, as IPO underpricing reduces the risk of lawsuits (Ibbotson, 1975) and the risk of a failed IPO (Welch, 1992). Recently, Cirillo et al. (2015) find that family firms positively influence IPO value, although the authors measure IPO value differently by separately considering offering and closing price, and by including accountingbased information.

Other empirical studies investigate differences between family and nonfamily firms for several stock exchange-related phenomena, by focusing mainly on the presence of principal- 
principal information asymmetries and the importance of retention of control. For instance, family-controlled firms are found to have higher voting premiums (Caprio \& Croci, 2008), have increased liquidity when double voting rights are used (Ginglinger \& Hamon, 2012), and have a higher price of vote in unifications (Hauser \& Lauterbach, 2004) than nonfamily firms. In addition, a number of studies focus on the cost of equity capital in listed family firms in relation to various other topics, for example to the Asian financial crisis (Boubakri et al., 2010), to CSR practices in listed Taiwanese firms (Wu et al., 2014), or to corporate governance attributes (Tran, 2014). Finally, the recent study by Jain and Shao (2015) investigates the financial policy choices following an IPO, and find that family firms have a higher leverage, prefer a longer debt maturity structure, and raise less external capital post-IPO compared to non-family firms.

\section{Retained Earnings Versus Dividends}

Pecking order theory states that firms prefer to finance new investments first internally, through retained earnings (Myers, 1984). All earnings that are retained in the firm, however, cannot be distributed as dividends. This has led researchers to examine this trade-off (retained earnings versus dividend payouts) that family businesses are facing when deciding on how to allocate their earnings. The majority of the articles study dividend policy in the context of publicly-held firms, and about half of the dividend articles in our literature review focus on firms in Asia, where many economies are characterized by considerable family ownership of listed corporations (Chen et al., 2005). The studies in our sample investigate one (or more) of the following aspects of dividend policy: propensity to pay dividends, dividend payout level or dividend smoothing.

Regarding the propensity to pay dividends, researchers found family firms to be less likely to pay dividends than nonfamily firms because of their stronger focus on the firm's long term orientation (Lace et al., 2013). Within the group of family firms, SMEs (How, Verhoeven \& Wu, 2008) and private family firms with passive family shareholders (Michiels, 
Voordeckers, Lybaert \& Steijvers, 2015) are more likely to pay dividends than other family firms, mainly explained by information asymmetries between majority and minority shareholders.

A large group of studies on the topic of dividend policy particularly examines the level of dividend payout. Most researchers agree that family firms have higher dividend payout levels than nonfamily firms (Chen et al., 2005; Carney \& Gedajlovic, 2002, Yoshikawa \& Rasheed, 2010; Setia-Atmaj, Tanewski \& Skully, 2009; Pindado, Requejo \& Torre, 2012; Huang, Chen $\&$ Kao, 2012). These studies thus find support for the expropriation hypothesis, according to which paying dividends is a mechanism that can be used to align the interests of controlling family and minority shareholders (Faccio et al., 2001; Setia-Atmaja et al., 2009). Thus, the higher dividend payouts of family firms might be considered as a result of investors demanding higher dividend payouts from companies with the highest risk of expropriation of minority shareholders.

Risk arguments are also often used to explain the higher dividend payout levels of family firms. Some authors explain the higher dividends in family firms by using risk aversion arguments. Family firm owners consider high retained earnings as an undesirable concentration of firm-specific risk (Carney \& Gedajlovic, 2002; Huang et al., 2012) and a more concrete threat to their welfare than a decline in the stock price (DeAngelo \& DeAngelo, 2000), and therefore prefer dividends which can be reinvested in other firms or which can be used for personal consumption. Other authors focus on arguments of control risk (or retention of control) to explain the higher dividend payouts of family firms. For example, to enhance their wealth through capital gains, family firm owners will have to sell their shareholdings, which will dilute their control over the firm (Yoshikawa \& Rasheed, 2010; Vandemaele \& Vancauteren, 2015). Also, when a family has low levels of cash flow rights, controlling families of public firms are found to pay higher dividends in order to preserve personal wealth due to the threat to lose 
control at any time (Huang et al., 2012). In addition, several studies confirm the importance of taking into account the heterogeneity of family businesses when studying dividend payout. For example, family SMEs are found to pay out more dividends than larger family firms (How et al., 2008). Family influence on dividend policy was also proven to vary depending on family involvement in ownership, management and control, for a sample of private firms (Vandemaele \& Vancauteren, 2015) and a sample consisting of both private and public firms (González, Gúzman, Pomp \& Trujillo, 2014). The theoretical arguments used in both papers differ and includes factors such as retention of control or information asymmetries between shareholders.

Regarding dividend smoothing, family firms are found to have less stable dividends than state-owned firms (He et al., 2012) and nonfamily firms (Gugler, 2003), which suggests that family firms can adjust their dividend policy as investment opportunities or financing needs occur and thus have more freedom in making financing decisions. On the contrary, Pindado et al. (2012), who use a more extensive database than the abovementioned studies (using data from 645 public firms in 9 different countries, over a period of 10 years) find that family firms distribute more stable dividends than nonfamily firms. These authors argue that family firms smooth their dividends to avoid future financing constraints such as running out of capital and thereby compromising profitable future investments. In comparison to the work of Gugler (2003) the authors do not focus on principal-agent but on principal-principal agency problems.

\section{A Framework to Understand Family Business Financing Decisions}

In Figure 1, we present a framework which structures the extant literature on financing decisions in family firms. As has become clear from the above literature review, several factors complicate a thorough understanding of family business financing decisions and may lead to inconsistent results: the theoretical arguments applied, the demand- versus supply-side focus, the comparison between family and nonfamily firms or within the group of family firms, and contextual factors. Appendix B gives an overview of the extant literature reviewed in this article 
and how to frame these studies in the structure of Figure 1. This framework will also be used in the next section to structure suggestions to further develop the field in the future.

Insert Figure 1 Here

\section{WHERE SHOULD WE GO?}

Based on the literature review above and on the results of an enquiry of an expert panel in the area of finance and/or family businesses, this section discusses opportunities and challenges for future research in the field of financing decisions in family firms. We discuss opportunities and challenges across theoretical perspectives, as well as across context-specific elements. Suggestions of potential research questions are stated throughout the text and are summarized in Table 2.

\section{Future Research Opportunities and Challenges Across Theoretical Perspectives}

Researchers have been questioning the applicability of classical agency theory to family firms because of the absence of a separation between ownership and control, especially in privately-held family businesses (Anderson and Reeb, 2003; Ang et al., 2000). Still, agency theory and other traditional finance theories such as pecking order theory and trade-off theory are among the dominant frameworks used by family business researchers in studying financing decisions (Titman \& Wessels, 1988; Harris \& Raviv, 1991; Fama \& French, 2002; Frank \& Goyal 2003). However, a number of limitations to the applicability of these traditional finance theories to explain family business financing decisions are worth getting attention.

First, the agency theory, pecking order theory and trade-off theory are all based on the wealth maximization principle of organizations, assuming that mainly financial motives will influence financing decisions. More specifically, the trade-off theory assumes that firms are 
trying to reach an optimal debt level by balancing the costs of debt against the benefits of debt (Kraus \& Litzenberger, 1973). As such, this theory partly relies on agency theory to identify costs related to information asymmetries between shareholders and bondholders, and benefits related to the potential of debt financing in reducing information asymmetries between shareholders and managers. Pecking order theory focuses on the diminishing preference in using retained earnings, then debt and finally external equity, based on information asymmetry costs linked to these different forms of financing (Myers, 1984). While these financial arguments can be applied to family businesses, financing behavior in family firms is not exclusively driven by financial motives, but also by non-economic considerations such as the risk-taking propensity, emotions, preferred values and goals of the family. Thus, traditional finance theories, in their current form, are unable to fully explain financing behavior in family firms. Therefore, it is worth investigating further how behavioral arguments (such as, for example, SEW, theory of planned behavior, stewardship theory) relate to each other and to the dominant agency perspective for explaining financing behavior. Despite the increasing attention to the behavioral financing approach, it remains an under-researched topic that has much potential in analyzing financing decisions in family firms. Future research that links noneconomic considerations such as family business goals and risk preferences to capital structure decisions would fill a gap in the literature on the actual incentives and motives of family owners to steer capital structure decisions. A way to open this black-box can be through qualitative research, which is very relevant in examining and understanding processes (Pratt, 2009; Langley \& Abdallah, 2011), but at the same time it allows answering "why" and "how" questions which are very difficult to answer through quantitative research methods (Reay, 2014). Relying on interviews, case studies or observations would enable scholars to significantly improve our knowledge on why certain sources of financing are used in family firms and how financing decisions are taken in reality (Shyu \& Lee, 2009; Koropp et al., 2014). 
Qualitative case study research is also ideal to help sharpen existing theory by pointing to gaps and beginning to fill them (Siggelkow, 2007). Alternatively, when performing quantitative research, a multi-respondent approach in which all persons potentially involved in the financial decision-making process are questioned, would on the one hand allow researchers to gain representativeness by forming a consensus-based dataset in which method biases caused by individual respondents' affect or mood are reduced (e.g., Chua et al., 1999; Podsakoff et al., 2003). On the other hand, dispersion models that take into account discord among family members are interesting to explore as well in the analysis of financial decision making in family firms (see Holt, Madison \& Kellermanns, 2017). This way, broader and deeper theoretical insights on the financial decision-making process can be obtained.

A second main limitation of the traditional finance theories is that they do not clearly distinguish between the demand and supply side of financing. If family businesses for example make less use of certain sources of financing, the main question is whether this is because of a restricted access to external financing (supply) or because of a lower willingness to attract financing (demand). In the traditional finance theories both perspectives can be detected. For the trade-off and agency theory, the agency costs of debt between shareholders and debtholders refer to the supply side of financing as it forms one of the main arguments why some family businesses are constrained in attracting financing. With respect to the demand side we can refer to the costs of financial distress which increases the reluctance to use debt financing, or to the debt control mechanism which can stimulate family business owners to use debt financing to reduce information asymmetries between managers and themselves. When turning to pecking order theory, both perspectives can be detected as well. The information asymmetry costs linked to certain forms of financing put constraints on the provisions of external financing to family firms (supply), leading to a sequential order in the preference of using various sources of financing (demand). Thus, in developing and testing hypotheses, and in selecting and 
constructing samples, future research should make a clear distinction between supply-side and demand-side perspectives. Otherwise, findings will be biased as they will not be able to separate demand-side from supply-side arguments in explaining the relation(s) found.

Furthermore, following a behavioral approach extends our knowledge on the demand side of financing, which is only partially captured by the traditional finance theories, and to gain more knowledge on how it relates to the supply-side factors of financing. Especially the SEW perspective (Gómez-Mejía et al., 2007), which is based on behavioral agency theory in management literature, appears to be a promising framework to study demand aspects of financing decisions in family businesses. Preservation of SEW is usually an important objective for many family-owned businesses, which translates itself among others in keeping independence and control in ownership, exerting control over the company's strategic direction, limiting the role of outside directors in the board, building strong and long-term relations based on trust, decision-making affected by emotions and sentiments, and long-term evaluation of investments (Berrone et al., 2012). Each of these factors is likely to impact the willingness of family businesses to use various sources of financing, extending our view on the demand side of financing. In addition, SEW arguments can also be linked to the availability of external financing (supply), since capital suppliers might take these arguments into account as well when making financing/investment decisions. In this respect, future research might investigate whether SEW aspects in family firms are considered either a risk-enhancing or a risk-reducing motive by capital suppliers? Overall, SEW could provide benefits to the finance field by integrating the idea that family firms are willing to sacrifice economic gains in order to preserve noneconomic utility. At the same time family business financing could also be an interesting context to deepen our knowledge on the theoretical underpinnings of SEW, which still need further attention and development (Chua et al., 2015). In addition, also other non-traditional behavioral perspectives such as the stewardship theory or the theory of planned behavior form 
promising theoretical frameworks for future studies in this field, as they consider noneconomic goals and pro-organizational behavior in the family firm (stewardship theory), and norms, attitudes, perceived behavioral control and behavioral intentions of family owners/managers (theory of planned behavior).

Another important aspect in explaining the demand side of financing revolves around the interaction between financing and growth, and the extent to which capital structure and growth are determined by the willingness to borrow versus the willingness to grow. In the extant literature, financing and growth behavior have been studied separately, although several studies suggest that financing and growth are interrelated. According to pecking order approach growth is an important determinant when analyzing the capital structure of a company (Fama \& French, 2002). Other studies point at the impact of a firm's capital structure on a firm's growth rate, where firm growth is constrained by the availability of financial resources (Carpenter \& Petersen, 2002; Oliveira \& Fortunato, 2006). It is therefore important for future research to further explore the simultaneous interaction between a firm's debt level and growth rate and potential endogeneity by using the appropriate estimation techniques such as simultaneous equations analysis, as demonstrated for example in the work of Molly et al. (2012).

Next, traditional frameworks such as pecking order theory also need a more extended and detailed view beyond the use of classic financing forms such as retained earnings, debt and external equity. For example, alternative forms of financing such as leasing, crowdfunding, mini bonds, state-subsidized loans, subordinated loans and intermingling between firm and household finances should be incorporated in these traditional theories. This way, scholars can make an interesting and incremental contribution to family business literature by modifying existing theories to improve their explanatory power (Reay \& Whetten, 2011).

\section{Future Research Opportunities and Challenges Across Context-Specific Elements}

\section{Heterogeneity Among Family Firms}


In analyzing the articles on financing decisions in family firms, a significant number of studies do not integrate the criteria to identify family firms. Our review shows that about $25 \%$ of the articles published after 2010 still lacks a clear family business definition. The remaining studies define family firms in very diverging ways. This is especially troublesome because it hampers the accumulation of knowledge (Schulze \& Gedajlovic, 2010). In light of this discussion in family business literature on what exactly characterizes a family business, we urge researchers to take fully into account the family firm definition used in their sample, in order to enhance cross-study comparison of research results. Moreover, we also recommend scholars to focus more strongly on the heterogeneity of family businesses and how this influences their financing decisions, since the majority of articles exclusively takes into account the oversimplified comparison between family and nonfamily firms. Family firms could indeed have a peculiar financial logic, but this is likely to be influenced by a variety of factors that can be traced back to the internal characteristics of the family and the business, and of the external environment as well. As such, we are echoing recent calls for research that have been made by Chua et al. (2012) and Nordqvist et al. (2014) to go beyond comparisons between family and nonfamily firms and to focus on the heterogeneous nature of this type of organization. Most studies in our review rely on secondary data which often do not account for this family business heterogeneity in a refined way. Analysis based on detailed survey data or qualitative research could deepen our knowledge in this direction. In addition, meta-analyses could bring more clarity as well in the various dichotomies that can be found in the literature (e.g., do family firms pay out more or less dividends?).

This heterogeneous nature could be captured by taking into account the different goals, governance structures and resources they have (Chua et al., 2012; Chrisman \& Patel, 2012; Chrisman et al., 2013). As these three drivers are considered to be the sources of differences in behavior among family firms as well as between family and nonfamily firms (De Massis et al., 
2014; Chrisman \& Holt, 2016), they provide an excellent basis to distinguish between different types of family firms to investigate financing decisions in the remainder of this article.

Goal-related sources of heterogeneity that might broaden our insight into the financing decisions of family firms are, for example, the importance family owners place on SEW goals. As indicated above, researchers have started to rely on the SEW premise in order to explain financing behavior of family firms. Yet, none of these studies have directly measured SEW, which, essentially makes it hard to indicate what exactly drives family firm financing behavior. In this sense, the socioemotional wealth importance scale (SEWi), recently developed by Debicki et al. (2016) could be an interesting measure. Future research might use this scale to test how the importance of SEW influences financing behavior of family firms in comparison to nonfamily firms and how variations in the importance attached to SEW leads to heterogeneous financing decisions among family firms. As an example, it would be interesting to investigate whether the use of collateral is influenced by the family owners' risk tolerance and willingness to give up control. Additionally, although researchers generally only focus on SEW loss aversion in financial decision making (risk of losing control, financial risk aversion), we encourage future research that investigates the impact of potential SEW gains on financing decisions as well. After all, family firms may prioritize financial goals when the socioemotional gains of these goals are perceived as outweighing socioemotional costs. Thus, family firms may sometimes choose not to pursue SEW goals when the second order, negative socioemotional effects (i.e. the socioemotional costs) are expected to be too large (Martin \& Gomez-Mejia, 2016).

Governance-related sources of heterogeneity arise from the family's involvement in ownership and management and can also lead to a wide variety of outcomes (Chua et al., 2012). Next to investigating the difference in importance placed on socioemotional concerns, the discretion that family members have in pursuing those concerns are important to take into 
account (Chrisman \& Holt, 2016). Since capital structure decisions are normally influenced or taken by the board of directors, the role and quality of this board are likely to affect financing decisions in family firms. Future research could therefore study the effect of board characteristics on the amount of debt financing that is applied for; and the process through which financing decisions are taken within the board and/or the management of the company. In contrast to nonfamily firms, the sustainability of family firms depends not only on the success of the firm, but also on the functionality of the family (Stafford et al., 1999). Thus, as the business family also needs to be governed, specific family governance mechanisms might be installed in the firm. Through these family governance mechanisms, family members can, for example, be informed about interesting investment opportunities, thereby raising the families' awareness of the negative second order effects that are associated with SEW goals (Martin \& Gomez-Mejia, 2016). An interesting avenue for future research might therefore be to investigate whether family governance influences the willingness to, for example, take on external equity or extra bank financing (demand-side) or to adapt dividend payouts. In addition, both corporate and family governance mechanisms implemented within the family business might be taken into account by external investors or loan officers. More specifically, having a formalized board of directors, and/or well-functioning family governance practices might be a sign of professionalization to capital suppliers. Future research could investigate whether this higher professionalization degree indeed influences the ability to obtain external financing (supplyside).

Family firm goals are also likely to change when the firm moves from one generation to another, and the financing challenge is likely to become even bigger over generations (Coleman \& Carsky, 1999). Future research is needed to provide us with further insight into the extent to which financing decisions in family firms are time-varying and depending on the family and firm's life stage. For example, factors worth investigating concern: the changing 
goal orientation and risk behavior of founders versus successors, the relationship and conflicts between different generations of family members, the changing ownership and management structure pre- versus post-succession, the type of succession, the source of transition funding, etc. The role of family offices in intergenerational wealth creation and preservation also forms an interesting avenue for future research (see Zellweger \& Kammerlander, 2015, for a profound theoretical overview on this topic).

Apart from investigating the importance family members place on socioemotional wealth and other concerns, and their ability to pursue those concerns, also the family firm's capabilities to achieve these goals are important aspects to consider (Chrisman \& Holt, 2016). Examples of resource-related sources of heterogeneity that could be taken into account when examining financing decisions in family firms are, for example: the availability of family-based human assets (Verbeke and Kano, 2012), the ability to professionalize the firm (Chua et al., 2003), or the presence of venture capital, which can influence the resources available to the firm both in quantity and quality. Therefore, future research could investigate how these resource-related aspects influence the availability of external financing (supply) as well as the willingness (demand) to attract debt or equity financing. Another interesting research direction related to the human resources available to the family firm, concerns the impact of gender on financing decisions in family firms. Although women's access to, and use of, debt (e.g., Coleman, 2004; Francis et al., 2013; Constantinidis et al., 2006), angel capital (Becker-Blease \& Sohl, 2007), and bootstrap financing (Neeley \& Van Auken, 2010) has been explored in finance and entrepreneurship journals, none of these studies has considered the family firm or family CEO contingency. Yet, the impact of having a female CEO on a firm's financing choices might be different for family firms than for nonfamily firms and might also differ within the group of family firms. Additionally, woman entrepreneurship studies have emphasized that afemale business owners tend to balance economic goals with noneconomic goals more often 
than their male counterparts (Hechavarria et al., 2012; Jennings \& Brush, 2013; Sullivan \& Meek, 2012). Thus, future research could investigate whether female and male family business managers tend to differ with respect to financing decisions by using the socioemotional wealth perspective. A similar ongoing debate worth investigating concerns the impact of visible minorities in the board or management team on a family firms' financing choices (e.g., Coleman 2004; Cavalluzzo \& Cavalluzzo, 1998).

Firm size can also lead to heterogeneity among family firms, as it might explain the goals, governance and resources of family firms (Chua et al., 2012). As indicated by the literature review, most of the studies are oriented towards large public firms even though, in reality, small private firms are the norm. The findings resulting from samples of large listed family businesses cannot automatically be transferred to privately-owned companies that usually are of a much smaller size, and thus more explicit evidence is required on this size effect. For example, many small family firms will be confronted with financial illiteracy (Koropp et al., 2013), which could be addressed partially through the financial advice provided by bankers or accountants. However, the literature is quite silent on the financial knowledge and competencies of family owners and their reliance on financial advice. Also, firm age could be an important factor in explaining financing decisions, as relationship lending could play a significant role in getting bank financing for companies with a longer history. However, little knowledge exists on this topic, thus warranting further research on, for example, how the family's history, generation and legacy influences this relationship. We recognize, however, that this presents "both an opportunity and a challenge to future research, as access to data from a large sample of these [privately-held] firms is severely limited" (Gómez-Mejía, LarrazaKintana \& Makri, 2003, p 236).

\section{Heterogeneity Across Countries}


The majority of empirical articles in our review are single-country studies. This is somewhat surprising, given that several researchers have pointed to the large differences that occur between countries regarding their level of investor and creditor protection, their level of development of financial markets, the degree to which the capital markets are bank-centered, their culture, and their legal framework (civil versus common-law) (Driffield et al., 2007; King \& Santor, 2008; Lappainen \& Niskanen, 2013; Santos et al., 2014). For example, several countries have introduced rules to correcting the incentive to take on excessive debt, such as limiting the deductibility of interest costs (France, Germany, Hungary, Spain, Italy) or extending the deductibility to include the cost of equity financing (Belgium, Italy, Portugal) (European Commission, 2015b). These incentives might significantly influence decisions on capital structure and dividend payout. More investigation into these country-level factors, and how they can be differentiated from firm-level effects, on family firm financing behavior, are thus warranted. Performing these multi-country studies might also clarify some of the inconsistent results on family business financing found in extant studies (see, for example the multi-country study of Pindado et al., 2012 on dividend smoothing).

In addition, longitudinal approaches could allow for capturing the consequences for family business financing behavior that result from certain policy shifts due to taxation (e.g., the changes in deductibility of interest costs, as discussed above), banking regulation (e.g., the implementation of Basel III) or financial-economic shocks. More specifically, taxation rules might discourage family firms to take on debt or pay out dividends in some countries, whereas they will not in other countries. So as to be able to compare studies, and to find explanations for contrasting results, we urge researchers to discuss the taxation rules applicable in their sample country, and, in case of a multi-country study, to thoroughly review the differences in taxation rules. 
Finally, future research could examine how a major crisis such as the global financial crisis that began in 2007 has affected financing decisions in family firms. After all, periods of economic downturn could strongly influence financing decisions in family businesses given the reduced availability of capital and other sources of financing. Apart from a number of articles in this direction, more efforts are needed to significantly broaden our knowledge on how financial crises impact family firm financing decisions (Amann \& Jaussaud, 2012; Boubakri et al., 2010: Pindado et al., 2012). Possible research questions are abundant. For example: the effect of a financial crisis on voluntary delistings, the use of private equity, the commitment to pay dividends, and so on. Again, we especially encourage researchers to take into account the heterogeneity of family firms when examining the impact of economic shocks or crises.

Insert Table 2 Here

\section{CONCLUSION}

Motivated by the growing attention to family firms in general, and their financing decisions in particular, this review brings together the two highly-relevant research fields of family business and finance. As the knowledge and contributions on financing decisions in family firms are quite dispersed, we develop a state of the art on family business financing literature and present a model to guide future research by identifying gaps across the theoretical perspectives, the demand versus supply side of financing, and across contexts. More specifically, we discuss the arguments underlying traditional theories and elaborate on their applicability to study financing decisions in family businesses. We also present future research opportunities and challenges across the context-specific elements such as family business heterogeneity and country-specific factors. We hope that our review provides finance scholars 
with fruitful research ideas which eventually will contribute to advance our understanding of family firm financing behavior in theory and practice. 


\section{REFERENCES}

Sample articles of the literature review are marked with an asterisk.

* Achleitner, A. K., Herman, K., Lerner, J., \& Lutz, E. (2010). Family business and private equity: conflict or collaboration? The case of Messer Griesheim. The Journal of Private Equity, 13(3), 7-20.

* Adams, A. F., Manners, G. E., Astrachan, J. H., \& Mazzola, P. (2004). The Importance of Integrated Goal Setting: The Application of Cost-of-Capital Concepts to Private Firms. Family Business Review, 17(4), 287-302.

* Ahlers, O., Hack, A., \& Kellermanns, F. W. (2014). "Stepping into the buyers' shoes": Looking at the value of family firms through the eyes of private equity investors. Journal of Family Business Strategy, 5(4), 384-396.

Ajzen, I. (1991). The theory of planned behavior. Organizational behavior and human decision processes, 50(2), 179211.

* Al-Ajmi, J., Abo Hussain, H., \& Al-Saleh, N. (2009). Decisions on capital structure in a Zakat environment with prohibition of riba: the case of Saudi Arabia. The journal of risk finance, 10(5), 460-476.

* Alekneviciene, V. (2012). Cost of Equity Capital in Agricultural Organizations: Theoretical Approach and Empirical Analysis. Economics and Rural Development, 7.

* Amann, B., \& Jaussaud, J. (2012). Family and non-family business resilience in an economic downturn. Asia Pacific business review, 18(2), 203-223.

* Amore, M. D., Minichilli, A., \& Corbetta, G. (2011). How do managerial successions shape corporate financial policies in family firms? Journal of Corporate Finance, 17(4), 1016-1027.

* Anderson, R. C., Mansi, S. A., \& Reeb, D. M. (2003). Founding family ownership and the agency cost of debt. Journal of Financial economics, 68(2), 263-285.

* Anderson, R. C., \& Reeb, D. M. (2003). Founding-Family Ownership, Corporate Diversification, and Firm Leverage. Journal of Law and Economics, 46(2), 653-684.

Ang, J. S., Cole, R. A., \& Lin, J. W. (2000). Agency costs and ownership structure. The Journal of Finance, 55(1), 81106.

* Astrachan, J. H., \& McConaughy, D. L. (2001). Venture Capitalists and Closely Held IPOs: Lessons for FamilyControlled Firms. Family Business Review, 14(4), 295-312.

* Attig, N., El Ghoul, S., Guedhami, O., \& Rizeanu, S. (2013). The governance role of multiple large shareholders: evidence from the valuation of cash holdings. Journal of Management \& Governance, 17(2), 419-451.

* Bagnoli, M., Liu, H. T., \& Watts, S. G. (2011). Family firms, debtholder-shareholder agency costs and the use of covenants in private debt. Annals of Finance, 7(4), 477-509.

Barton, S. L., \& Matthews, C. H. (1989). Small firm financing: implications from a strategic management perspective. Journall of Small Business Management, 27(1), 1-7.

* Batten, J., \& Hettihewa, S. (1999). Small firm behaviour in Sri Lanka. Small Business Economics, 13(3), 201-217.

Beck, T., \& Demirguc-Kunt, A. (2006). Small and medium-size enterprises: Access to finance as a growth constraint. Journal of Banking \& Finance,30(11), 2931-2943

Becker-Blease, J. R., \& Sohl, J. E. (2007). Do women-owned businesses have equal access to angel capital?. Journal of Business Venturing, 22(4), 503-521

Benavides-Velasco, C.A., Quintana-García, C., \& Guzmán-Parra, V.F. (2013). Trends in family business research. Small Business Economics, 40(1), 41-57.

* Benito-Hernández, S., Priede-Bergamini, T., \& López-Cózar-Navarro, C. (2014). Factors determining exportation and internationalization in family businesses: The importance of debt. South African Journal of Business Management, 45(1), 13-25.

* Berghoff, H. (2013). Blending personal and managerial capitalism: Bertelsmann's rise from medium-sized publisher to global media corporation and service provider, 1950-2010. Business History, 55(6), 855-874.

Berrone, P., Cruz, C., \& Gomez-Mejia, L. R. (2012). Socioemotional wealth in family firms theoretical dimensions, assessment approaches, and agenda for future research. Family Business Review, 25(3), 258-279.

* Bhattacharya, U., \& Ravikumar, B. (2001). Capital Markets and the Evolution of Family Businesses. The Journal of Business, 74(2), 187-219.

* Bjuggren, P. O., Duggal, R., \& Giang, D. T. (2012). Ownership Dispersion and Capital Structures in Family Firms: A Study of Closed Medium-sized Enterprises. Journal of Small Business \& Entrepreneurship, 25(2), 185-200.

* Blanco-Mazagatos, V., Quevedo-Puente, D., \& Castrillo, L. A. (2007). The Trade-Off Between Financial Resources and Agency Costs in the Family Business: An Exploratory Study. Family Business Review, 20(3), 199-213.

* Bopiah, C. (1998). Availability of credit to family business. Small Business Economics, 11(1), 75-86.

* Boubakri, N., \& Ghouma, H. (2010). Control/ownership structure, creditor rights protection, and the cost of debt financing: International evidence. Journal of Banking \& Finance, 34(10), 2481-2499. 
* Boubakri, N., Guedhami, O., \& Mishra, D. (2010). Family control and the implied cost of equity: Evidence before and after the Asian financial crisis. Journal of International Business Studies, 41(3), 451-474.

* Burgstaller, J., \& Wagner, E. (2015). How do family ownership and founder management affect capital structure decisions and adjustment of SMEs? Evidence from a bank-based economy. The Journal of Risk Finance, 16(1), 73-101.

* Caprio, L., \& Croci, E. (2008). The determinants of the voting premium in Italy: the evidence from 1974 to 2003. Journal of Banking \& Finance, 32(11), 2433-2443.

* Carney, M., \& Gedajlovic, E. (2002). The coupling of ownership and control and the allocation of financial resources: Evidence from Hong Kong. Journal of Management Studies, 39(1), 123-146.

Carpenter, R.E. \& Petersen, B.C. (2002). Is the growth of small firms constrained by internal finance? The Review of Economics and Statistics, 84(2), 298-309.

Cavalluzzo, K. S., \& Cavalluzzo, L. C. (1998). Market structure and discrimination: The case of small businesses. Journal of Money, Credit and Banking, 771-792

* Chaganti, R., \& Damanpour, F. (1991). Institutional ownership, capital structure, and firm performance. Strategic Management Journal, 12(7), 479-491.

* Chan, K. S., Dang, V. Q., \& Yan, I. K. (2012). Chinese firms’ political connection, ownership, and financing constraints. Economics Letters, 115(2), 164-167.

* Chen, Z., Cheung, Y. L., Stouraitis, A., \& Wong, A. W. (2005). Ownership concentration, firm performance, and dividend policy in Hong Kong. Pacific-Basin Finance Journal, 13(4), 431-449.

* Chen, Q., Ding, S., Wu, Z., \& Yang, F. (2016). Family control, international accounting standards, and access to foreign banks: Evidence from international entrepreneurial firms. Journal of Small Business Management, 54(2), 598-621

Chrisman, J. J., \& Patel, P. C. (2012). Variations in R\&D investments of family and nonfamily firms: Behavioral agency and myopic loss aversion perspectives. Academy of management Journal, 55(4), 976-997.

Chrisman, J. J., \& Holt, D. T. (2016). Beyond socioemotional wealth: taking another step toward a theory of the family firm. Management Research: Journal of the Iberoamerican Academy of Management, 14(3), 249-287.

Chrisman, J. J., Sharma, P., Steier, L. P., \& Chua, J. H. (2013). The influence of family goals, governance, and resources on firm outcomes. Entrepreneurship Theory and Practice, 37(6), 1249-1261.

Chua, J. H., Chrisman, J. J., \& Sharma, P. (2003). Succession and nonsuccession concerns of family firms and agency relationship with nonfamily managers. Family Business Review, 16(2), 89-107.

* Chua, J. H., Chrisman, J. J., Kellermanns, F., \& Wu, Z. (2011). Family involvement and new venture debt financing. Journal of Business Venturing, 26(4), 472-488.

Chua, J. H., Chrisman, J. J., Steier, L. P., \& Rau, S. B. (2012). Sources of heterogeneity in family firms: An introduction. Entrepreneurship Theory and Practice, 36(6), 1103-1113.

Chua, J. H., Chrisman, J. J., \& De Massis, A. (2015). A closer look at socioemotional wealth: its flows, stocks, and prospects for moving forward.Entrepreneurship Theory and Practice, 39(2), 173-182

* Cirillo, A., Romano, M., \& Ardovino, O. (2015). Does family involvement foster IPO value? Empirical analysis on Italian stock market. Management Decision, 53(5), 1125-1154.

Coleman, S. (2004). Access to debt capital for women-and minority-owned small firms: does educational attainment have an impact?. Journal of Developmental Entrepreneurship, 9(2), 127

* Coleman, S., \& Carsky, M. (1999). Sources of Capital for Small Family-Owned Businesses Evidence from the National Survey of Small Business Finances. Family Business Review, 12(1), 73-84.

Constantinidis, C., Cornet, A., \& Asandei, S. (2006). Financing of women-owned ventures: The impact of gender and other owner-and firm-related variables. Venture Capital, 8(02), 133-157

* Croci, E., Doukas, J. A., \& Gonenc, H. (2011). Family control and financing decisions. European Financial Management, 17(5), 860-897.

* Dailey, R. C., Reuschling, T. E., \& De Mong, R. F. (1977). The family owned business: Capital funding. American Journal of Small Business, 2(2), 30-39.

David, R. J., \& Han, S. K. (2004). A systematic assessment of the empirical support for transaction cost economics. Strategic management journal, 25(1), 39-58.

Davis, J. H., Schoorman, F. D., \& Donaldson, L. (1997). Toward a stewardship theory of management. Academy of Management review, 22(1), 20-47.

* Dawson, A. (2011). Private equity investment decisions in family firms: The role of human resources and agency costs. Journal of Business Venturing, 26(2), 189-199.

* DeAngelo, H., \& DeAngelo, L. (2000). Controlling stockholders and the disciplinary role of corporate payout policy: A study of the Times Mirror Company. Journal of Financial Economics, 56(2), 153-207. 
Debicki, B. J., Kellermanns, F. W., Chrisman, J. J., Pearson, A. W., \& Spencer, B. A. (2016). Development of a socioemotional wealth importance (SEWi) scale for family firm research. Journal of Family Business Strategy, $7(1), 47-57$.

* Dejung, C. (2013). Worldwide ties: The role of family business in global trade in the nineteenth and twentieth centuries. Business History, 55(6), 1001-1018.

De Massis, A., Kotlar, J., Chua, J. H., \& Chrisman, J. J. (2014). Ability and willingness as sufficiency conditions for family-oriented particularistic behavior: implications for theory and empirical studies. Journal of Small Business Management, 52(2), 344-364.

* Desbrières, P., \& Schatt, A. (2002). The impacts of LBOs on the performance of acquired firms: the French case. Journal of Business Finance \& Accounting, 29(5-6), 695-729.

* Di Giuli, A., Caselli, S., \& Gatti, S. (2011). Are small family firms financially sophisticated?. Journal of Banking \& Finance, 35(11), 2931-2944.

* Ding, H. B., \& Pukthuanthong-Le, K. (2009). Family firm IPO performance and market signals. Journal of Enterprising Culture, 17(01), 55-77.

* Dreux, D. R. (1990). Financing family business: Alternatives to selling out or going public. Family Business Review, 3(3), 225-243.

* Driffield, N., Mahambare, V., \& Pal, S. (2007). How does ownership structure affect capital structure and firm value? Recent evidence from East Asia1. Economics of Transition, 15(3), 535-573.

* Ebihara, T., Kubota, K., Takehara, H., \& Yokota, E. (2014). Market liquidity, private information, and the cost of capital: Market microstructure studies on family firms in Japan. Japan and the World Economy, 32, 1-13.

* Ehrhardt, O., \& Nowak, E. (2003). The Effect of IPOs on German Family-Owned Firms: Governance Changes, Ownership Structure, and Performance. Journal of Small Business Management, 41(2), 222-232.

* El-Chaarani, H. (2013). The success keys for family firms: A comparison between Lebanese and French systems. Journal of Business and Retail Management Research, 8(1).

European commission (2015). Promoting entrepreneurship: Family business - Main challenges faced by family firms. Retrieved from: http://ec.europa.eu/growth/smes/promoting-entrepreneurship/we-work-for/familybusiness/index en.htm

European commission (2015b). Tax Reforms in EU Member States 2015 Tax policy challenges for economic growth and fiscal sustainability. Retrieved from: http://ec.europa.eu/economy_finance/publications/eeip/pdf/ip008_en.pdf

Faccio, M., Lang, L. H. P., \& Young, L. (2001). Dividends and expropriation. American Economic Review, 54-78.

* Faccio, M., \& Parsley, D. C. (2009). Sudden deaths: Taking stock of geographic ties. Journal of Financial and Quantitative Analysis, 44(03), 683-718.

Fama, E. F. (1978). The effects of a firm's investment and financing decisions on the welfare of its security holders. The American Economic Review, 68(3), 272-284

Fama, E.F., \& French, K.R. (2002). Testing trade-off and pecking order predictions about dividends and debt. The Review of Financial Studies, 15(1), 1-33.

* Fernando, G. D., Schneible, R. A., \& Suh, S. (2014). Family firms and institutional investors. Family Business Review, 27(4), 328-345.

* Fitó, M. À., Moya, S., \& Orgaz, N. (2013). The debate on rented assets capitalization: The economic impact on family firms. Journal of Family Business Strategy, 4(4), 260-269.

Francis, B., Hasan, I., \& Wu, Q. (2013). The impact of CFO gender on bank loan contracting. Journal of Accounting, Auditing \& Finance, 28(1), 53-78

Frank, M.Z., \& Goyal, V.K. (2003). Testing the pecking order theory of capital structure. Journal of Financial Economics, 67(2), 217-248.

Gallo, M. Á., Tàpies, J., \& Cappuyns, K. (2004). Comparison of family and nonfamily business: Financial logic and personal preferences. Family Business Review, 17(4), 303-318

* Gallo, M. A., \& Vilaseca, A. (1996). Finance in family business. Family Business Review, 9(4), 387-401.

* Ginglinger, E., \& Hamon, J. (2012). Ownership, control and market liquidity. Finance, 33(2), 61-99.

Gómez-Mejía, L. R., Larraza-Kintana, M., \& Makri, M. (2003). The determinants of executive compensation in familycontrolled public corporations. Academy of management journal, 46(2), 226-237

Gómez-Mejía, L. R., Haynes, K. T., Núñez-Nickel, M., Jacobson, K. J., \& Moyano-Fuentes, J. (2007). Socioemotional wealth and business risks in family-controlled firms: Evidence from Spanish olive oil mills. Administrative science quarterly, 52(1), 106-137

* González, M., Guzmán, A., Pombo, C., \& Trujillo, M. A. (2013). Family firms and debt: Risk aversion versus risk of losing control. Journal of Business Research, 66(11), 2308-2320.

* González, M., Guzmán, A., Pombo, C., \& Trujillo, M. A. (2014). Family involvement and dividend policy in closely held firms. Family Business Review, 27(4), 365-385. 
* Gugler, K. (2003). Corporate governance, dividend payout policy, and the interrelation between dividends, R\&D, and capital investment. Journal of Banking \& Finance, 27(7), 1297-1321.

* Hakim, T., Lypny, G., \& Bhabra, H. S. (2012). IPO lockup expiration in the Middle East and North Africa. Journal of Multinational Financial Management, 22(5), 252-262.

Harris, M., \& Raviv, A. (1991). The theory of capital structure. The Journal of Finance, 46(1), 297-355.

* Hauser, S., \& Lauterbach, B. (2004). The value of voting rights to majority shareholders: Evidence from dual-class stock unifications. Review of Financial Studies, 17(4), 1167-1184.

* Haynes, G. W., Walker, R., Rowe, B. R., \& Hong, G. S. (1999). The intermingling of business and family finances in family-owned businesses. Family Business Review, 12(3), 225-239.

* He, T. T., Li, W. X., \& Tang, G. Y. (2012). Dividends behavior in state-versus family-controlled firms: Evidence from Hong Kong. Journal of business ethics, 110(1), 97-112.

* He, T. T., Li, W. X., \& Tang, G. Y. (2013). Dividends, Controlling Shareholders And Firm Performance: An Investigation Of Large Firms On The Hong Kong Stock Exchange. Annals of Financial Economics, 8(02), 1350011.

* Hearn, B. (2011). The performance and the effects of family control in North African IPOs. International Review of Financial Analysis, 20(3), 140-151.

* Hearn, B. (2014). The political institutional and firm governance determinants of liquidity: Evidence from North Africa and the Arab Spring. Journal of International Financial Markets, Institutions and Money, 31, 127-158.

Hechavarria, D. M., Ingram, A., Justo, R., \& Terjesen, S. (2012). Are women more likely to pursue social and environmental entrepreneurship. Global women's entrepreneurship research: Diverse settings, questions and approaches, 135-151

Holt, D. T., Madison, K., \& Kellermanns, F. W. (2017). Variance in family members' assessments: The importance of dispersion modeling in family firm research. Family Business Review, 30(1), 61-83.

* How, J., Verhoeven, P., \& Wu, C. (2008). Dividends and expropriation in Hong Kong. Asian academy of management journal of accounting and finance, 4(1), 71-85.

* Huang, Y., Chen, A., \& Kao, L. (2012). Corporate governance in Taiwan: The nonmonotonic relationship between family ownership and dividend policy. Asia Pacific Journal of Management, 29(1), 39-58.

Hutchinson, R. W. (1995). The capital structure and investment decisions of the small owner-managed firm: some exploratory issues. Small Business Economics, 7(3), 231-239.

Ibbotson, R. G. (1975). Price performance of common stock new issues.Journal of financial economics, 2(3), 235-272

* Jain, B. A., \& Shao, Y. (2015). Family Firm Governance and Financial Policy Choices in Newly Public Firms. Corporate Governance: An International Review, 23(5), 452-468.

* Keasey, K., Martinez, B., \& Pindado, J. (2015). Young family firms: Financing decisions and the willingness to dilute control. Journal of Corporate Finance, 34, 47-63.

Jennings, J. E., \& Brush, C. G. (2013). Research on women entrepreneurs: challenges to (and from) the broader entrepreneurship literature?. The Academy of Management Annals, 7(1), 663-715.

Jensen, M. C., \& Meckling, W. H. (1976). Theory of the firm: Managerial behavior, agency costs and ownership structure. Journal of financial economics, 3(4), 305-360.

Jones, O., \& Gatrell, C. (2014). Editorial: the future of writing and reviewing for IJMR. International Journal of Management Reviews, 16(3), 249-264

* Kimhi, A. (1997). Intergenerational succession in small family businesses: Borrowing constraints and optimal timing of succession. Small Business Economics, 9(4), 309-318.

* King, R., \& Peng, W. Q. (2013). The effect of industry characteristics on the control longevity of founding-family firms. Journal of Family Business Strategy, 4(4), 281-295.

* King, M. R., \& Santor, E. (2008). Family values: Ownership structure, performance and capital structure of Canadian firms. Journal of Banking \& Finance, 32(11), 2423-2432.

Kontinen, T., \& Ojala, A. (2010). The internationalization of family businesses: A review of extant research. Journal of Family Business Strategy, 1(2), 97-107.

* Koropp, C., Grichnik, D., \& Gygax, A. F. (2013b). Succession financing in family firms. Small Business Economics, 41(2), 315-334.

* Koropp, C., Grichnik, D., \& Kellermanns, F. (2013). Financial attitudes in family firms: The moderating role of family commitment. Journal of Small Business Management, 51(1), 114-137.

* Koropp, C., Kellermanns, F. W., Grichnik, D., \& Stanley, L. (2014). Financial Decision Making in Family Firms An Adaptation of the Theory of Planned Behavior. Family Business Review, 0894486514522483.

Kraus, A., \& Litzenberger, R. H. (1973). A state-preference model of optimal financial leverage. The journal of finance, 28(4), 911-922.

* Kusnadi, Y. (2011). Do corporate governance mechanisms matter for cash holdings and firm value?. Pacific-Basin Finance Journal, 19(5), 554-570. 
* Lace, N., Bistrova, J., \& Kozlovskis, K. (2013). Ownership type influence on dividend payments in CEE countries. Business: Theory and Practice/Verslas: Teorija ir Praktika, 14(3), 259-266.

* Landry, S., Fortin, A., \& Callimaci, A. (2013). Family firms and the lease decision. Journal of Family Business Strategy, 4(3), 176-187.

Langley, A., \& Abdallah, C. (2011). Templates and turns in qualitative studies of strategy and management: Building methodological bridges. Research Methodology in Strategy and Management, 6, 201-235.

* Lappalainen, J., \& Niskanen, M. (2013). Behavior and attitudes of small family firms towards different funding sources. Journal of Small Business \& Entrepreneurship, 26(6), 579-599.

* Leitterstorf, M. P., \& Rau, S. B. (2014). Socioemotional wealth and IPO underpricing of family firms. Strategic Management Journal, 35(5), 751-760.

* Lin, C. P., \& Chuang, C. M. (2011). Principal-Principal Conflicts and IPO Pricing in an Emerging Economy. Corporate Governance: An International Review, 19(6), 585-600.

* López-Gracia, J., \& Sánchez-Andújar, S. (2007). Financial structure of the family business: Evidence from a group of small Spanish firms. Family Business Review, 20(4), 269-287.

* Mahérault, L. (2004). Is there Any Specific Equity Route for Small and Medium-Sized Family Businesses? The French Experience. Family Business Review, 17(3), 221-235.

* Martí, J., Menéndez-Requejo, S., \& Rottke, O. M. (2013). The impact of venture capital on family businesses: Evidence from Spain. Journal of World Business, 48(3), 420-430.

Martin, G., \& Gomez-Mejia, L. (2016). The relationship between socioemotional and financial wealth: re-visiting family firm decision making. Management Research: Journal of the Iberoamerican Academy of Management, $14(3), 215-233$.

* Martinez, I., \& Serve, S. (2011). The delisting decision: the case of buyout offer with squeeze-out (BOSO). International Review of Law and Economics, 31(4), 228-239.

* Masulis, R. W., Pham, P. K., \& Zein, J. (2011). Family business groups around the world: financing advantages, control motivations, and organizational choices. Review of Financial Studies, 24(3), 556-600.

* Matias Gama, A. P., \& Manuel Mendes Galvão, J. (2012). Performance, valuation and capital structure: survey of family firms. Corporate Governance: The international journal of business in society, 12(2), 199-214.

* Maula, M., Autio, E., \& Arenius, P. (2005). What drives micro-angel investments?. Small Business Economics, 25(5), 459-475.

* Mazzola, P., \& Marchisio, G. (2002). The Role of Going Public in Family Businesses' Long-Lasting Growth: A Study of Italian IPOs. Family Business Review, 15(2), 133-148.

* McConaughy, D. L. (1999). Is the cost of capital different for family firms?. Family Business Review, 12(4), 353360.

* McConaughy, D. L., Matthews, C. H., \& Fialko, A. S. (2001). Founding family controlled firms: Performance, risk, and value. Journal of small business management, 39(1), 31-49.

* Michiels, A., Voordeckers, W., Lybaert, N., \& Steijvers, T. (2015). Dividends and family governance practices in private family firms. Small Business Economics, 44(2), 299-314.

Modigliani, F., \& Miller, M. H. (1958). The cost of capital, corporation finance and the theory of investment. The American economic review, 48(3), 261-297

* Mishra, C. S., \& McConaughy, D. L. (1999). Founding family control and capital structure: The risk of loss of control and the aversion to debt. Entrepreneurship: Theory and Practice, 23(4), 53-53.

* Molly, V., Laveren, E., \& Deloof, M. (2010). Family business succession and its impact on financial structure and performance. Family Business Review, 23(2), 131-147.

* Molly, V., Laveren, E., \& Jorissen, A. (2012). Intergenerational differences in family firms: Impact on capital structure and growth behavior. Entrepreneurship Theory and Practice, 36(4), 703-725.

* Muske, G., Fitzgerald, M. A., Haynes, G., Black, M., Chin, L., MacClure, R., \& Mashburn, A. (2009). The intermingling of family and business financial resources: Understanding the copreneurial couple. Journal of Financial Counseling and Planning, 20(2), 27.

Myers, S. C. (1984). The capital structure puzzle. The journal of finance, 39(3), 574-592.

Myers, S. C. (1989). Still searching for optimal capital structure. Are the distinctions between debt and equity disappearing, 80-95.

Myers, S. C., \& Majluf, N. S. (1984). Corporate financing and investment decisions when firms have information that investors do not have. Journal of financial economics, 13(2), 187-221

* Napoli, F. (2012). The board's strategic and control tasks; family firms and their search for outside directors to support growth. Journal of General Management, 37(4).

Neeley, L., \& Van Auken, H. (2010). Differences Between Female And Male Entrepreneurs'use Of Bootstrap Financing. Journal of Developmental Entrepreneurship, 15(01), 19-34 
* Nielsen, R. P. (2008). The private equity-leveraged buyout form of finance capitalism: Ethical and social issues, and potential reforms. Business Ethics Quarterly, 379-404.

* Noordin, A., Ariffin, B., \& Law, S. H. (2008). Family Control Business and Capital Market Development in ASEAN. Journal of Financial Economics, 6(1), 46-55.

Nordqvist, M., Sharma, P., \& Chirico, F. (2014). Family firm heterogeneity and governance: A configuration approach. Journal of Small Business Management, 52(2), 192-209.

O'Regan, N., Hughes, T., Collins, L., \& Tucker, J. (2010). Strategic thinking in family businesses. Strategic Change, 19(1-2), 57-76.

Oliveira, B. \& Fortunato, A. (2006). Firm growth and liquidity constraints: a dynamic analysis. Small Business Economics, 27(2-3), 139-156.

* Pindado, J., Requejo, I., \& Torre, C. (2012). Do family firms use dividend policy as a governance mechanism? Evidence from the Euro zone. Corporate Governance: An International Review, 20(5), 413-431.

* Pindado, J., Requejo, I., \& la Torre, C. (2015). Does family control shape corporate capital structure? An empirical analysis of Eurozone firms. Journal of Business Finance \& Accounting, 42(7-8), 965-1006.

* Poutziouris, P. Z. (2001). The Views of Family Companies on Venture Capital: Empirical Evidence from the UK Small to Medium-Size Enterprising Economy. Family Business Review, 14(3), 277-291.

* Poutziouris, P. (2011). The financial structure and performance of owner-managed family firms: Evidence from the UK economy/Estructura financiera y rentabilidad en empresas familiares gestionadas por la propiedad: evidencias de la economía inglesa. Universia Business Review, (32), 70.

Pratt, M. (2009). For the lack of a boilerplate: Tips on writing up (and reviewing) qualitative research. Academy of Management Journal, 52, 856-862.

* Psillaki, M., \& Eleftheriou, K. (2015). Trade credit, bank credit, and flight to quality: Evidence from French SMEs. Journal of Small Business Management, 53(4), 1219-1240

Pukall, T. J., \& Calabrò, A. (2014). The Internationalization of Family Firms A Critical Review and Integrative Model. Family Business Review, 27(2), 103-125.

Reay, T. (2014). Publishing qualitative research. Family Business Review, 27(2), 95-102..

Reay, T., \& Whetten, D. A. (2011). What constitutes a theoretical contribution in family business?. Family Business Review, 24(2), 105-110.

* Romano, C. A., Tanewski, G. A., \& Smyrnios, K. X. (2001). Capital structure decision making: A model for family business. Journal of business venturing, 16(3), 285-310.

Salvato, C., \& Moores, K. (2010). Research on accounting in family firms: Past accomplishments and future challenges. Family Business Review, 23(3), 193-215.

* Santos, M. S., Moreira, A. C., \& Vieira, E. S. (2014). Ownership concentration, contestability, family firms, and capital structure. Journal of Management \& Governance, 18(4), 1063-1107.

* Schmid, T. (2013). Control considerations, creditor monitoring, and the capital structure of family firms. Journal of Banking \& Finance, 37(2), 257-272.

* Scholes, M. L., Wright, M., Westhead, P., Burrows, A., \& Bruining, H. (2007). Information sharing, price negotiation and management buy-outs of private family-owned firms. Small Business Economics, 29(3), 329-349.

* Scholes, L., Wright, M., Westhead, P., Bruining, H., \& Kloeckner, O. (2009). Family Firm Buy-Outs, Private Equity and Strategic Change. Private Equity and Strategic Change, 12(2), 7-18.

Schulze, W. S., \& Gedajlovic, E. R. (2010). Whither family business?. Journal of Management Studies, 47(2), 191204.

* Schulze, W. S., Lubatkin, M. H., \& Dino, R. N. (2003). Exploring the agency consequences of ownership dispersion among the directors of private family firms. Academy of Management Journal, 46(2), 179-194.

* Segura, L. C., \& Formigoni, H. (2014). Influence of Control and Family Management in the Indebtedness of Brazilian Open Business: a Quantitative Study. Brazilian Business Review, 11(6), 50.

* Setia-Atmaja, L., Tanewski, G. A., \& Skully, M. (2009). The role of dividends, debt and board structure in the governance of family controlled firms. Journal of Business Finance \& Accounting, 36(7-8), 863-898.

* Shyu, Y. W., \& Lee, C. I. (2009). Excess Control Rights and Debt Maturity Structure in Family-Controlled Firms. Corporate Governance: An International Review, 17(5), 611-628.

Siebels, J. F., \& zu Knyphausen-Aufseß, D. (2012). A review of theory in family business research: The implications for corporate governance.International Journal of Management Reviews, 14(3), 280-304.

Siggelkow, N. (2007). Persuasion with case studies. Academy of Management Journal, 50(1), 20-24.

Sullivan, D. M., \& Meek, W. R. (2012). Gender and entrepreneurship: a review and process model. Journal of Managerial Psychology, 27(5), 428-458.

* Song, H., \& Wang, L. (2013). The impact of private and family firms' relational strength on financing performance in clusters. Asia Pacific Journal of Management, 30(3), 735-748. 
Stafford, K., Duncan, K. A., Dane, S., \& Winter, M. (1999). A research model of sustainable family businesses. Family Business Review, 12(3), 197-208.

* Steijvers, T., \& Voordeckers, W. (2009). Private family ownership and the agency costs of debt. Family Business Review, 22(4), 333-346.

* Steijvers, T., Voordeckers, W., \& Vanhoof, K. (2010). Collateral, relationship lending and family firms. Small Business Economics, 34(3), 243-259.

* Strebulaev, I. A., \& Yang, B. (2013). The mystery of zero-leverage firms. Journal of Financial Economics, 109(1), $1-23$.

Stiglitz, J. E. (1969). A re-examination of the Modigliani-Miller theorem. The American Economic Review, 59(5), 784793.

Stiglitz, J. E. (1974). On the irrelevance of corporate financial policy. The American Economic Review, 64(6), 851866.

* Tanaka, T. (2014). Corporate governance and the cost of public debt financing: Evidence from Japan. Journal of the Japanese and International Economies, 34, 315-335.

* Tappeiner, F., Howorth, C., Achleitner, A. K., \& Schraml, S. (2012). Demand for private equity minority investments: A study of large family firms. Journal of Family Business Strategy, 3(1), 38-51.

Titman, S., \& Wessels, R. (1988). The determinants of capital structure choice. The Journal of Finance, 43(1), 1-19.

* Tran, H. T., \& Santarelli, E. (2014). Capital constraints and the performance of entrepreneurial firms in Vietnam. Industrial and Corporate Change, 23(3), 827-864.

* Tran, D. H. (2014). Multiple corporate governance attributes and the cost of capital-Evidence from Germany. The British Accounting Review, 46(2), 179-197.

* Upton, N., \& Petty, W. (2000). Venture capital investment and US family business. Venture Capital: An International Journal of Entrepreneurial Finance, 2(1), 27-39.

* Vandemaele, S., \& Vancauteren, M. (2015). Nonfinancial Goals, Governance, and Dividend Payout in Private Family Firms. Journal of Small Business Management, 53(1), 166-182.

Verbeke, A., \& Kano, L. (2012). The transaction cost economics theory of the family firm: Family-based human asset specificity and the bifurcation bias. Entrepreneurship Theory and Practice, 36(6), 1183-1205.

* Viviani, D., Giorgino, M., \& Steri, R. (2008). Private equity-backed IPOs and long-run market performance analysis of Italian firms. The Journal of Private Equity, 11(3), 50.

* Voordeckers, W., \& Steijvers, T. (2006). Business collateral and personal commitments in SME lending. Journal of Banking \& Finance, 30(11), 3067-3086.

Voordeckers, W., Le Breton-Miller, I., \& Miller, D.(2014). In Search of the Best of Both Worlds: Crafting a Finance Paper for the Family Business Review, Family Business Review, (27(4), 281-286.

* Waisman, M. (2013). Product market competition and the cost of bank loans: Evidence from state antitakeover laws. Journal of Banking \& Finance, 37(12), 4721-4737.

* Walker, T. (2008). Family control, underwriter prestige, and IPO underpricing: a cross country analysis. Multinational Business Review, 16(2), 1-42.

Welch, I. (1992). Sequential sales, learning, and cascades. The Journal of finance, 47(2), 695-732.

Wiseman, R. M., \& Gomez-Mejia, L. R. (1998). A behavioral agency model of managerial risk taking. Academy of management Review, 23(1), 133-153.

* Wright, M., Amess, K., Weir, C., \& Girma, S. (2009). Private equity and corporate governance: Retrospect and prospect. Corporate Governance: An International Review, 17(3), 353-375.

* Wu, Z., Chua, J. H., \& Chrisman, J. J. (2007). Effects of family ownership and management on small business equity financing. Journal of Business Venturing, 22(6), 875-895.

* Wu, S. W., Lin, F., \& Wu, C. M. (2014). Corporate social responsibility and cost of capital: An empirical study of the Taiwan stock market. Emerging Markets Finance and Trade, 50(sup1), 107-120.

* Yen, J. F., Lin, C. Y., Chen, Y. S., \& Huang, Y. C. (2015). Founding family firms and bank loan contracts. Journal of Financial Services Research, 48(1), 53-82.

* Yilmazer, T., \& Schrank, H. (2006). Financial intermingling in small family businesses. Journal of Business Venturing, 21(5), 726-751.

* Yoshikawa, T., \& Rasheed, A. A. (2010). Family Control and Ownership Monitoring in Family-Controlled Firms in Japan. Journal of Management Studies, 47(2), 274-295.

* Yu, X., \& Zheng, Y. (2012). IPO underpricing to retain family control under concentrated ownership: evidence from Hong Kong. Journal of Business Finance \& Accounting, 39(5-6), 700-729.

Zahra, S. A., Hayton, J. C., Neubaum, D. O., Dibrell, C., \& Craig, J. (2008). Culture of family commitment and strategic flexibility: The moderating effect of stewardship. Entrepreneurship theory and practice, 32(6), 1035-1054.

Zahra, S. A., \& Sharma, P. (2004). Family business research: A strategic reflection. Family Business Review, 17(4), 331-346. 
* Zellweger, T., \& Kammerlander, N. (2015). Family, wealth, and governance: an agency account. Entrepreneurship Theory and Practice, 39(6), 1281-1303.

* Zhang, X., Venus, J., \& Wang, Y. (2012). Family ownership and business expansion of small-and medium-sized Chinese family businesses: The mediating role of financing preference. Journal of Family Business Strategy, 3(2), 97-105.

\author{
Anneleen Michiels, Hasselt University, Belgium \\ Vincent Molly, KU Leuven, Antwerp Management School, Belgium
}

The authors would like to thank a panel of experts that provided valuable insights for this review, based on their experience as a family business and/or finance scholar and/or editor of a prominent family business journal: Joseph Astrachan, Joern Block, Marc Deloof, Luis Gomez-Mejia, Danny Miller, Pannikos Poutziouris, Alessandro Minichilli, Wim Voordeckers, and Pramodita Sharma. We are also grateful for the helpful comments from Daniel Holt and three anonymous FBR reviewers on earlier versions of this article. The authors contributed equally to this article and are therefore listed alphabetically. 


\section{TABLES \& FIGURES}

Table 1: Methodological parameters

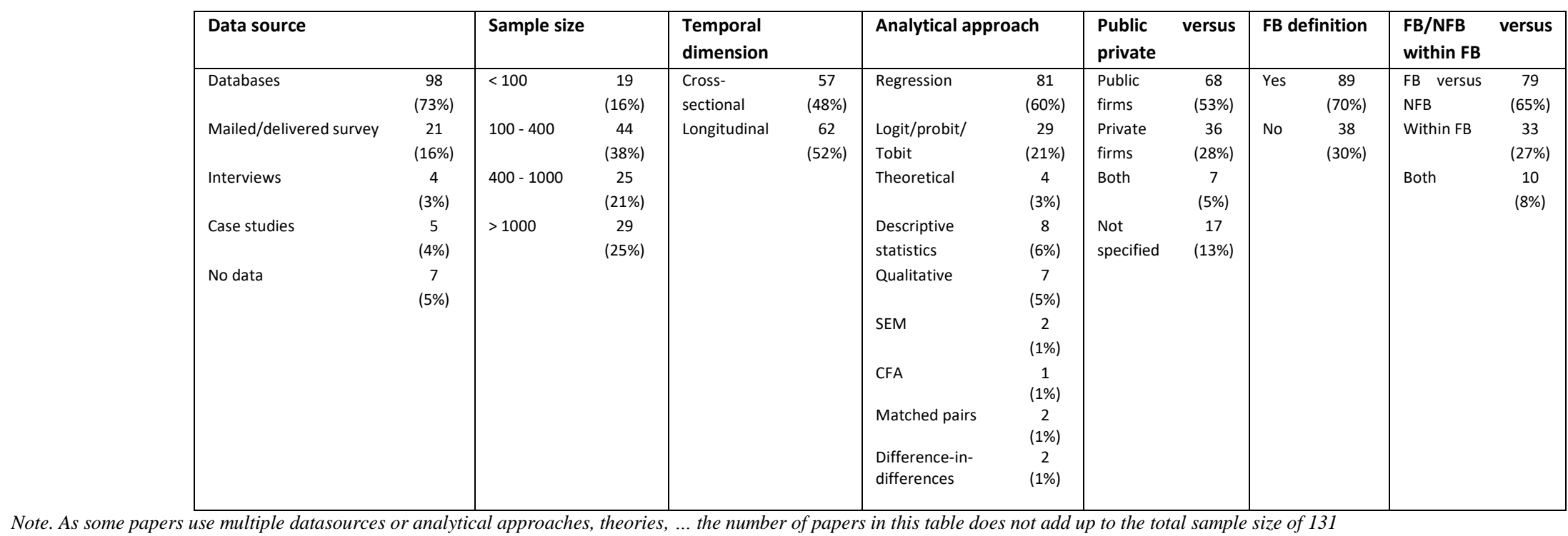


Figure 1: Framework for organizing research on financing decisions in family businesses

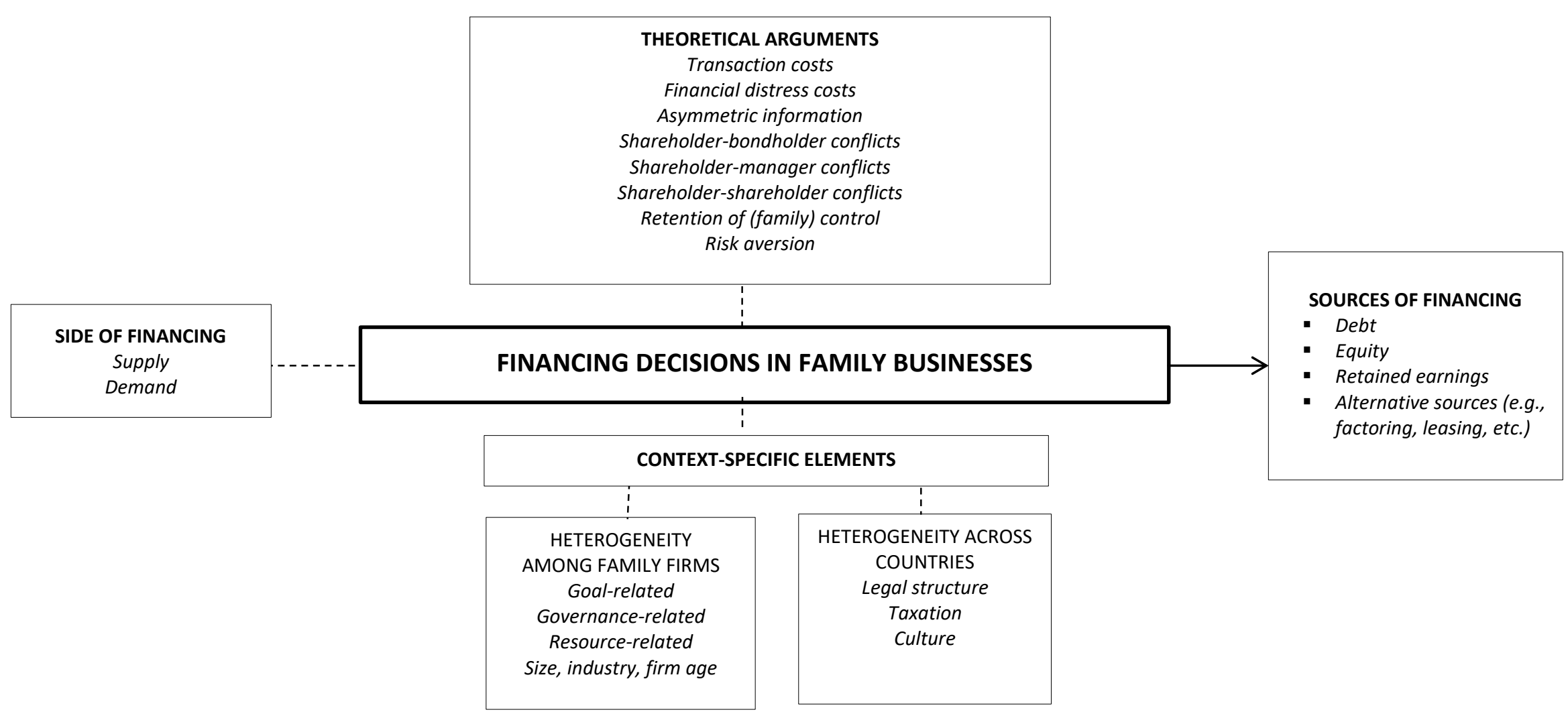


Table 2. Potential Future Research Questions on Financing Decisions within Family Firms

\begin{tabular}{|c|c|c|c|}
\hline Gaps & $\begin{array}{l}\text { Demand/ } \\
\text { Supply side }\end{array}$ & $\begin{array}{l}\text { Source of } \\
\text { financing }\end{array}$ & Possible Research Questions \\
\hline Theoretical & Both & Various & $\begin{array}{l}\text { How do behavioral arguments for explaining financing behavior (such as SEW or stewardship theory) relate to each } \\
\text { other and to the dominant agency perspective?; How are non-economic considerations such as family business goals } \\
\text { and risk preferences related to capital structure decisions?; How could the socioemotional wealth perspective extend } \\
\text { our view on the demand side of financing?; How could alternative forms of financing such as leasing, crowdfunding, } \\
\text { mini bonds, state-subsidize or subordinated loans and intermingling between firm and household finance be } \\
\text { incorporated into the traditional finance theories? How does the importance of SEW influence financing behavior of } \\
\text { family firms in comparison to non-family firms? }\end{array}$ \\
\hline \multirow[t]{6}{*}{$\begin{array}{l}\text { Heterogeneity } \\
\text { across family } \\
\text { firms }\end{array}$} & Demand & Various & $\begin{array}{l}\text { Do variations in the importance attached to SEW lead to heterogeneous financing decisions among family firms?; } \\
\text { What is the impact of potential SEW gains on financing decisions?; Do female and male family business managers } \\
\text { tend to differ with respect to financing decisions?; What is the impact of visible minorities in the board or } \\
\text { management team on a family firm's financing choices?; What is the impact of the financial knowledge and } \\
\text { competencies of family owners and their reliance on financial advice on the financing decisions that are being taken?; } \\
\text { To what extent are financing decisions in family firms time-varying and depending on the family and the firm's life } \\
\text { stage? }\end{array}$ \\
\hline & Demand & Debt & $\begin{array}{l}\text { What is the effect of board characteristics on the amount of debt financing that is applied for?; How does the process } \\
\text { develop through which financing decisions are taken within the board and/or the management of the company; What } \\
\text { is the impact of family governance on the willingness to take on extra bank financing? }\end{array}$ \\
\hline & Demand & $\begin{array}{l}\text { External } \\
\text { equity }\end{array}$ & What is the impact of family governance on the willingness to take on external equity? \\
\hline & Demand & $\begin{array}{l}\text { Retained } \\
\text { earnings }\end{array}$ & What is the impact of family governance on the willingness to adapt dividend payouts? \\
\hline & Supply & $\begin{array}{l}\text { Debt, } \\
\text { external } \\
\text { equity }\end{array}$ & $\begin{array}{l}\text { Does the degree to which a family business is professionalized influence the access to external financing?; How does } \\
\text { the presence of venture capital influence access to bank debt? Are SEW aspects in family firms considered either as } \\
\text { a risk-enhancing or a risk-reducing motive by capital suppliers? }\end{array}$ \\
\hline & Supply & Debt & $\begin{array}{l}\text { What is the impact of relationship lending on getting bank financing for family businesses? How is relationship lending } \\
\text { influenced by generation? }\end{array}$ \\
\hline \multirow[t]{2}{*}{$\begin{array}{l}\text { Heterogeneity } \\
\text { across countries }\end{array}$} & Demand & Various & $\begin{array}{l}\text { What are the consequences for family business financing behavior that result from certain policy shifts due to } \\
\text { taxation? }\end{array}$ \\
\hline & Both & Various & $\begin{array}{l}\text { How can country-level factors be differentiated from firm-level effects on family firm financing behavior?; How has } \\
\text { the global financial crisis that began in } 2007 \text { affected the demand and supply of finance to family firms? }\end{array}$ \\
\hline
\end{tabular}




\section{Appendix A: Distribution of articles by journal}

\begin{tabular}{|c|c|c|c|}
\hline Journal & $\begin{array}{c}2016 \\
\text { Impact } \\
\text { Factor } \\
\end{array}$ & $\mathbf{N}$ & $\%$ \\
\hline Family Business Review & 4,229 & 17 & $12,98 \%$ \\
\hline Small Business Economics & 2,421 & 8 & $6,11 \%$ \\
\hline Journal of Banking \& Finance & 1,776 & 8 & $6,11 \%$ \\
\hline Journal of Family Business Strategy & 2,375 & 6 & $4,58 \%$ \\
\hline $\begin{array}{l}\text { Journal of Small Business } \\
\text { Management }\end{array}$ & 2,876 & 6 & $4,58 \%$ \\
\hline Journal of Business Venturing & 5,774 & 5 & $3,82 \%$ \\
\hline $\begin{array}{l}\text { Corporate Governance: An } \\
\text { International Review }\end{array}$ & 3,571 & 5 & $3,82 \%$ \\
\hline Journal of Financial Economics & 4,505 & 4 & $3,05 \%$ \\
\hline $\begin{array}{l}\text { Journal of Business Finance \& } \\
\text { Accounting }\end{array}$ & 1,276 & 4 & $3,05 \%$ \\
\hline $\begin{array}{l}\text { Entrepreneurship Theory and } \\
\text { Practice }\end{array}$ & 4,916 & 3 & $2,29 \%$ \\
\hline $\begin{array}{l}\text { Asia Pacific Journal of } \\
\text { Management }\end{array}$ & 2,024 & 2 & $1,53 \%$ \\
\hline Business History & 0,83 & 2 & $1,53 \%$ \\
\hline $\begin{array}{l}\text { Journal of Management \& } \\
\text { Governance }\end{array}$ & N/A & 2 & $1,53 \%$ \\
\hline Journal of Private Equity & N/A & 2 & $1,53 \%$ \\
\hline $\begin{array}{l}\text { Journal of Small Business \& } \\
\text { Entrepreneurship }\end{array}$ & N/A & 2 & $1,53 \%$ \\
\hline Journal of Management Studies & 3,962 & 2 & $1,53 \%$ \\
\hline Pacific-Basin Finance Journal & 1,754 & 2 & $1,53 \%$ \\
\hline Review of Financial Studies & 3,689 & 2 & $1,53 \%$ \\
\hline Strategic Management Journal & 4,461 & 2 & $1,53 \%$ \\
\hline The Journal of Risk Finance & N/A & 2 & $1,53 \%$ \\
\hline Journal of Corporate Finance & 1,579 & 2 & $1,53 \%$ \\
\hline Academy of Management Journal & 7,417 & 1 & $0,76 \%$ \\
\hline American Journal of Small Business & N/A & 1 & $0,76 \%$ \\
\hline Annals of Finance & N/A & 1 & $0,76 \%$ \\
\hline Annals of Financial Economics & N/A & 1 & $0,76 \%$ \\
\hline Asia Pacific Business Review & 1 & 1 & $0,76 \%$ \\
\hline $\begin{array}{l}\text { Asian Academy } \\
\text { of Management Journal of } \\
\text { Accounting \& Finance }\end{array}$ & N/A & 1 & $0,76 \%$ \\
\hline Brazilian Business Review & N/A & 1 & $0,76 \%$ \\
\hline British Accounting Review & 2,135 & 1 & $0,76 \%$ \\
\hline Business Ethics Quarterly & 1,703 & 1 & $0,76 \%$ \\
\hline Business: Theory \& Practice & N/A & 1 & $0,76 \%$ \\
\hline Economics \& Rural Development & N/A & 1 & $0,76 \%$ \\
\hline Economics Letters & 0,558 & 1 & $0,76 \%$ \\
\hline
\end{tabular}

\begin{tabular}{|c|c|c|c|}
\hline Journal & $\begin{array}{c}2016 \\
\text { Impact } \\
\text { Factor } \\
\end{array}$ & $\mathbf{N}$ & $\%$ \\
\hline Economics of Transition & 0,479 & 1 & $0,76 \%$ \\
\hline $\begin{array}{l}\text { Emerging Markets Finance \& } \\
\text { Trade }\end{array}$ & 0,826 & 1 & $0,76 \%$ \\
\hline European Financial Management & 1,236 & 1 & $0,76 \%$ \\
\hline Finance & N/A & 1 & $0,76 \%$ \\
\hline Industrial \& Corporate Change & 1,777 & 1 & $0,76 \%$ \\
\hline $\begin{array}{l}\text { International Review of Financial } \\
\text { Analysis }\end{array}$ & 1,457 & 1 & $0,76 \%$ \\
\hline $\begin{array}{l}\text { International Review of Law \& } \\
\text { Economics }\end{array}$ & 0,57 & 1 & $0,76 \%$ \\
\hline Japan \& the World Economy & 0,489 & 1 & $0,76 \%$ \\
\hline Journal of Business & 1,133 & 1 & $0,76 \%$ \\
\hline $\begin{array}{l}\text { Journal of Business \& Retail } \\
\text { Management Research }\end{array}$ & N/A & 1 & $0,76 \%$ \\
\hline Journal of Business Ethics & 2,354 & 1 & $0,76 \%$ \\
\hline Journal of Business Research & 3,354 & 1 & $0,76 \%$ \\
\hline Journal of Enterprising Culture & N/A & 1 & $0,76 \%$ \\
\hline $\begin{array}{l}\text { Journal of Financial \& Quantitative } \\
\text { Analysis }\end{array}$ & 1,673 & 1 & $0,76 \%$ \\
\hline $\begin{array}{l}\text { Journal of Financial Services } \\
\text { Research }\end{array}$ & 1,13 & 1 & $0,76 \%$ \\
\hline $\begin{array}{l}\text { Journal of Financial Counseling \& } \\
\text { Planning }\end{array}$ & N/A & 1 & $0,76 \%$ \\
\hline Journal of General Management & N/A & 1 & $0,76 \%$ \\
\hline $\begin{array}{l}\text { Journal of International Financial } \\
\text { Markets, Institutions \& Money }\end{array}$ & 1,379 & 1 & $0,76 \%$ \\
\hline $\begin{array}{l}\text { Journal of } \\
\text { International Business Studies }\end{array}$ & 5,869 & 1 & $0,76 \%$ \\
\hline Journal of Law \& Economics & 0,932 & 1 & $0,76 \%$ \\
\hline $\begin{array}{l}\text { Journal of Multinational Financial } \\
\text { Management }\end{array}$ & N/A & 1 & $0,76 \%$ \\
\hline $\begin{array}{l}\text { Journal of the Japanese \& } \\
\text { International Economies }\end{array}$ & 0,542 & 1 & $0,76 \%$ \\
\hline Journal of World Business & 3,758 & 1 & $0,76 \%$ \\
\hline Management Decision & 1,396 & 1 & $0,76 \%$ \\
\hline Multinational Business Review & N/A & 1 & $0,76 \%$ \\
\hline $\begin{array}{l}\text { South African Journal of Business } \\
\text { Management }\end{array}$ & 0,246 & 1 & $0,76 \%$ \\
\hline Strategic Change & N/A & 1 & $0,76 \%$ \\
\hline $\begin{array}{l}\text { The international journal of } \\
\text { business in society }\end{array}$ & N/A & 1 & $0,76 \%$ \\
\hline The Journal of Private Equity & N/A & 1 & $0,76 \%$ \\
\hline Universia Business Review & 0,138 & 1 & $0,76 \%$ \\
\hline Venture Capital & N/A & 1 & $0,76 \%$ \\
\hline TOTAL & & 131 & $100 \%$ \\
\hline
\end{tabular}




\section{Appendix B: Overview of extant literature on financing decisions in family firms}

\begin{tabular}{|c|c|c|c|c|c|}
\hline Author(s) & $\begin{array}{l}\text { Source of } \\
\text { financing }\end{array}$ & Theoretical arguments & $\begin{array}{l}\text { Demand or } \\
\text { supply }\end{array}$ & $\begin{array}{l}\text { FB/NFB or } \\
\text { within FB }\end{array}$ & $\begin{array}{l}\text { Country of } \\
\text { research }\end{array}$ \\
\hline Achleitner et al. (2010) & Equity & Retention of control & NA & Within FB & Germany \\
\hline Adams et al. (2004) & Multiple & Aversion to risk & Demand & NA & NA \\
\hline Ahlers et al. (2014) & Equity & NA & Supply & Within & NA \\
\hline Al-Ajmi et al. (2009) & Debt & $\begin{array}{l}\text { Asymmetric information between } \\
\text { shareholders and bondholders, and } \\
\text { between shareholders and } \\
\text { managers }\end{array}$ & NA & $\mathrm{FB} / \mathrm{NFB}$ & Saudi Arabia \\
\hline Alekneviciene (2012) & $\begin{array}{l}\text { Alternative } \\
\text { sources }\end{array}$ & NA & NA & $\mathrm{FB} / \mathrm{NFB}$ & Lithuania \\
\hline $\begin{array}{l}\text { Amann and Jaussaud } \\
\text { (2012) }\end{array}$ & Debt & Aversion to risk & Demand & $\mathrm{FB} / \mathrm{NFB}$ & Japan \\
\hline Amore et al. (2011) & Debt & $\begin{array}{l}\text { Free cash flow hypothesis, } \\
\text { retention of control, aversion to } \\
\text { risk }\end{array}$ & Demand & Within FB & Italy \\
\hline Anderson et al. (2003) & Debt & $\begin{array}{l}\text { Asymmetric information between } \\
\text { shareholders and bondholders }\end{array}$ & Supply & $\mathrm{FB} / \mathrm{NFB}$ & US \\
\hline $\begin{array}{l}\text { Anderson and Reeb } \\
\text { (2003) }\end{array}$ & Debt & $\begin{array}{l}\text { Asymmetric information between } \\
\text { shareholders and bondholders }\end{array}$ & Supply & $\mathrm{FB} / \mathrm{NFB}$ & US \\
\hline $\begin{array}{l}\text { Astrachan and } \\
\text { McConaughy (2001) }\end{array}$ & Equity & Signaling hypothesis & NA & $\mathrm{FB} / \mathrm{NFB}$ & US \\
\hline Attig et al. (2013) & $\begin{array}{l}\text { Alternative } \\
\text { sources }\end{array}$ & $\begin{array}{l}\text { Asymmetric information between } \\
\text { shareholders }\end{array}$ & Supply & Both & EU, Asia \\
\hline Bagnoli et al. (2011) & Debt & $\begin{array}{l}\text { Asymmetric information between } \\
\text { shareholders and bondholders }\end{array}$ & Supply & $\mathrm{FB} / \mathrm{NFB}$ & US \\
\hline $\begin{array}{l}\text { Batten and Hettihewa } \\
\text { (1999) }\end{array}$ & Debt & $\begin{array}{l}\text { Asymmetric information between } \\
\text { shareholders and bondholders }\end{array}$ & Supply & FB/NFB & Sri Lanka \\
\hline $\begin{array}{l}\text { Benito-Hernández et } \\
\text { al. (2014) }\end{array}$ & Debt & Retention of control & Demand & $\mathrm{FB} / \mathrm{NFB}$ & Spain \\
\hline Berghoff (2013) & Multiple & Transaction costs & NA & NA & Germany \\
\hline $\begin{array}{l}\text { Bhattacharya and } \\
\text { Ravikumar (2001) }\end{array}$ & Multiple & NA & Supply & Within FB & NA \\
\hline Bjuggren et al. (2012) & Debt & $\begin{array}{l}\text { Asymmetric information between } \\
\text { shareholders and bondholders, } \\
\text { Free cash flow hypothesis, aversion } \\
\text { to risk }\end{array}$ & Demand & $\mathrm{FB} / \mathrm{NFB}$ & Sweden \\
\hline $\begin{array}{l}\text { Blanco-Mazagatos et } \\
\text { al. (2007) }\end{array}$ & Multiple & $\begin{array}{l}\text { Free cash flow hypothesis, } \\
\text { retention of control, aversion to } \\
\text { risk }\end{array}$ & Demand & $\mathrm{FB} / \mathrm{NFB}$ & Spain \\
\hline Bopaiah (1998) & Debt & $\begin{array}{l}\text { Asymmetric information between } \\
\text { shareholders and bondholders }\end{array}$ & Supply & $\mathrm{FB} / \mathrm{NFB}$ & US \\
\hline $\begin{array}{l}\text { Boubakri and Ghouma } \\
\text { (2010) }\end{array}$ & Debt & $\begin{array}{l}\text { Asymmetric information between } \\
\text { shareholders and bondholders }\end{array}$ & Supply & FB/NFB & EU, Asia \\
\hline Boubakri et al. (2010) & Equity & $\begin{array}{l}\text { Asymmetric information between } \\
\text { shareholders }\end{array}$ & Supply & $\mathrm{FB} / \mathrm{NFB}$ & Asia \\
\hline $\begin{array}{l}\text { Burgstaller and } \\
\text { Wagner (2015) }\end{array}$ & Debt & $\begin{array}{l}\text { Retention of control, aversion to } \\
\text { risk }\end{array}$ & Demand & FB/NFB & Austria \\
\hline $\begin{array}{l}\text { Caprio and Croci } \\
(2008)\end{array}$ & Equity & $\begin{array}{l}\text { Asymmetric information between } \\
\text { shareholders, retention of control, }\end{array}$ & Supply & FB/NFB & Italy \\
\hline $\begin{array}{l}\text { Carney and Gedajlovic } \\
(2002)\end{array}$ & $\begin{array}{l}\text { Retained } \\
\text { earnings }\end{array}$ & Aversion to risk & Demand & $\mathrm{FB} / \mathrm{NFB}$ & Hong Kong \\
\hline $\begin{array}{l}\text { Chaganti and } \\
\text { Damanpour (1991) }\end{array}$ & Multiple & NA & Demand & $\mathrm{FB} / \mathrm{NFB}$ & US \\
\hline Chan et al. (2012) & Multiple & NA & Supply & $\mathrm{FB} / \mathrm{NFB}$ & China \\
\hline Chen et al. (2005) & $\begin{array}{l}\text { Retained } \\
\text { earnings }\end{array}$ & $\begin{array}{l}\text { Asymmetric information between } \\
\text { shareholders, retention of control, }\end{array}$ & Demand & $\mathrm{FB} / \mathrm{NFB}$ & Hong Kong \\
\hline Chen et al. (2016) & Debt & $\begin{array}{l}\text { Asymmetric information beween } \\
\text { lenders and borrowers }\end{array}$ & Supply & $\mathrm{FB} / \mathrm{NFB}$ & Multiple \\
\hline Chua et al. (2011) & Debt & $\begin{array}{l}\text { Asymmetric information between } \\
\text { shareholders and bondholders, } \\
\text { social capital }\end{array}$ & Supply & Both & US \\
\hline Cirillo et al. (2015) & Equity & Stewardship & Supply & Within FB & Italy \\
\hline $\begin{array}{l}\text { Coleman and Carsky } \\
\text { (1999) }\end{array}$ & Debt & NA & Demand & FB/NFB & US \\
\hline Croci et al. (2011) & Multiple & $\begin{array}{l}\text { Asymmetric information between } \\
\text { shareholders and bondholders, } \\
\text { retention of control }\end{array}$ & Both & $\mathrm{FB} / \mathrm{NFB}$ & EU \\
\hline
\end{tabular}




\begin{tabular}{|c|c|c|c|c|c|}
\hline Dailey et al. (1977) & Debt & $\begin{array}{l}\text { Asymmetric information between } \\
\text { shareholders and bondholders }\end{array}$ & NA & Within FB & US \\
\hline Dawson (2011) & Equity & $\begin{array}{l}\text { Asymmetric information between } \\
\text { shareholders }\end{array}$ & Supply & NA & Italy \\
\hline $\begin{array}{l}\text { DeAngelo and } \\
\text { DeAngelo (2000) }\end{array}$ & $\begin{array}{l}\text { Retained } \\
\text { earnings }\end{array}$ & $\begin{array}{l}\text { Asymmetric information between } \\
\text { shareholders }\end{array}$ & Demand & Within FB & US \\
\hline Dejung (2013) & Debt & NA & Demand & NA & Switzerland \\
\hline $\begin{array}{l}\text { Desbrières and Schatt } \\
(2002)\end{array}$ & Equity & NA & NA & $\mathrm{FB} / \mathrm{NFB}$ & France \\
\hline DiGiuli et al. (2011) & $\begin{array}{l}\text { Alternative } \\
\text { sources }\end{array}$ & NA & Demand & Within FB & Italy \\
\hline $\begin{array}{l}\text { Ding and } \\
\text { Pukthuanthong-Le } \\
\text { (2009) }\end{array}$ & Equity & $\begin{array}{l}\text { Asymmetric information between } \\
\text { shareholders }\end{array}$ & Supply & $\mathrm{FB} / \mathrm{NFB}$ & Taiwan \\
\hline Dreux (1990) & Multiple & NA & Both & NA & NA \\
\hline Driffield et al. (2007) & Debt & $\begin{array}{l}\text { Asymmetric information between } \\
\text { shareholders, and between } \\
\text { shareholders and managers, } \\
\text { aversion to risk }\end{array}$ & Demand & Both & Asia \\
\hline Ebihara et al. (2014) & Multiple & $\begin{array}{l}\text { Asymmetric information between } \\
\text { shareholders, retention of control }\end{array}$ & Demand & $\mathrm{FB} / \mathrm{NFB}$ & Japan \\
\hline $\begin{array}{l}\text { Ehrhardt and Nowak } \\
\text { (2003) }\end{array}$ & Equity & NA & NA & Within FB & Germany \\
\hline El-Chaarani (2013) & Debt & $\begin{array}{l}\text { Retention of control, aversion to } \\
\text { risk }\end{array}$ & Demand & Within FB & France, Libanon \\
\hline $\begin{array}{l}\text { Faccio and Parsley } \\
\text { (2009) }\end{array}$ & Debt & NA & Demand & $\mathrm{FB} / \mathrm{NFB}$ & Multiple \\
\hline Fernando et al. (2014) & Equity & $\begin{array}{l}\text { Asymmetric information between } \\
\text { shareholders }\end{array}$ & Supply & $\mathrm{FB} / \mathrm{NFB}$ & US \\
\hline Fitó et al. (2013) & Debt & Aversion to risk & Demand & $\mathrm{FB} / \mathrm{NFB}$ & Spain \\
\hline $\begin{array}{l}\text { Gallo and Vilaseca } \\
\text { (1996) }\end{array}$ & Multiple & $\begin{array}{l}\text { Aversion to risk, financial distress } \\
\text { costs }\end{array}$ & Both & Within FB & Spain \\
\hline $\begin{array}{l}\text { Ginglinger and Hamon } \\
\text { (2012) }\end{array}$ & Equity & $\begin{array}{l}\text { Asymmetric information between } \\
\text { shareholders, aversion to risk }\end{array}$ & NA & Both & France \\
\hline González et al. (2013) & Debt & $\begin{array}{l}\text { Asymmetric information between } \\
\text { shareholders and bondholders, free } \\
\text { cash flow hypothesis, retention of } \\
\text { control, aversion to risk }\end{array}$ & Both & $\mathrm{FB} / \mathrm{NFB}$ & Colombia \\
\hline González et al. (2014) & $\begin{array}{l}\text { Retained } \\
\text { earnings }\end{array}$ & $\begin{array}{l}\text { Asymmetric information between } \\
\text { shareholders }\end{array}$ & Demand & $\mathrm{FB} / \mathrm{NFB}$ & Colombia \\
\hline Gugler (2003) & $\begin{array}{l}\text { Retained } \\
\text { earnings }\end{array}$ & $\begin{array}{l}\text { Asymmetric information between } \\
\text { shareholders and managers }\end{array}$ & Demand & $\mathrm{FB} / \mathrm{NFB}$ & Austria \\
\hline Hakim et al. (2012) & Equity & $\begin{array}{l}\text { Asymmetric information between } \\
\text { shareholders }\end{array}$ & Supply & $\mathrm{FB} / \mathrm{NFB}$ & Multiple \\
\hline $\begin{array}{l}\text { Hauser and Lauterbach } \\
(2004)\end{array}$ & Equity & Retention of control & NA & $\mathrm{FB} / \mathrm{NFB}$ & Israel \\
\hline Haynes et al. (1999) & Debt & NA & Demand & $\mathrm{FB} / \mathrm{NFB}$ & US \\
\hline He et al. (2012) & $\begin{array}{l}\text { Retained } \\
\text { earnings }\end{array}$ & $\begin{array}{l}\text { Asymmetric information between } \\
\text { shareholders, retention of control }\end{array}$ & Demand & $\mathrm{FB} / \mathrm{NFB}$ & Hong Kong \\
\hline He et al. (2013) & $\begin{array}{l}\text { Retained } \\
\text { earnings }\end{array}$ & NA & Demand & $\mathrm{FB} / \mathrm{NFB}$ & Hong Kong \\
\hline Hearn (2011) & Equity & $\begin{array}{l}\text { Asymmetric information between } \\
\text { shareholders }\end{array}$ & Supply & Both & Africa \\
\hline Hearn (2014) & Equity & Transaction costs & Supply & $\mathrm{FB} / \mathrm{NFB}$ & Africa \\
\hline How et al. (2008) & Equity & $\begin{array}{l}\text { Asymmetric information between } \\
\text { shareholders }\end{array}$ & Demand & $\mathrm{FB} / \mathrm{NFB}$ & Hong Kong \\
\hline Huang et al. (2012) & $\begin{array}{l}\text { Retained } \\
\text { earnings }\end{array}$ & $\begin{array}{l}\text { Asymmetric information between } \\
\text { shareholders, retention of control }\end{array}$ & Demand & Within FB & Taiwan \\
\hline Jain and Shao (2015) & Multiple & $\begin{array}{l}\text { Asymmetric information between } \\
\text { shareholders, between } \\
\text { shareholders and managers, and } \\
\text { between shareholders and } \\
\text { bondholders, risk aversion, } \\
\text { retention of control, protection of } \\
\text { reputation }\end{array}$ & Both & Both & US \\
\hline Keasey et al. (2015) & Debt & $\begin{array}{l}\text { Retention of control, asymmetric } \\
\text { information between shareholders } \\
\text { and bondholders }\end{array}$ & Both & Both & EU \\
\hline Kimhi (1997) & Debt & NA & Supply & Within FB & NA \\
\hline King and Peng (2013) & Multiple & Aversion to risk & Demand & Within FB & US \\
\hline
\end{tabular}




\begin{tabular}{|c|c|c|c|c|c|}
\hline King and Santor (2008) & Debt & $\begin{array}{l}\text { Asymmetric information between } \\
\text { shareholders and bondholders, } \\
\text { aversion to risk }\end{array}$ & Demand & Both & Canada \\
\hline $\begin{array}{l}\text { Koropp, Grichnik and } \\
\text { Gygax (2013) }\end{array}$ & Debt & $\begin{array}{l}\text { Retention of control, aversion to } \\
\text { risk, debt use intention }\end{array}$ & Demand & Within FB & Germany \\
\hline $\begin{array}{l}\text { Koropp, Grichnik and } \\
\text { Kellermanns (2013) }\end{array}$ & Debt & Retention of control & Demand & Within FB & Germany \\
\hline Koropp et al. (2014) & Multiple & Retention of control & Demand & Within FB & Germany \\
\hline Kusnadi (2011) & $\begin{array}{l}\text { Alternative } \\
\text { sources }\end{array}$ & $\begin{array}{l}\text { Asymmetric information between } \\
\text { shareholders and managers }\end{array}$ & Demand & $\mathrm{FB} / \mathrm{NFB}$ & $\begin{array}{l}\text { Singapore, } \\
\text { Malaysia }\end{array}$ \\
\hline Lace et al. (2013) & $\begin{array}{l}\text { Retained } \\
\text { earnings }\end{array}$ & NA & Demand & $\mathrm{FB} / \mathrm{NFB}$ & EU \\
\hline Landry et al. (2013) & Multiple & $\begin{array}{l}\text { Retention of control, aversion to } \\
\text { risk }\end{array}$ & Demand & Both & Canada \\
\hline $\begin{array}{l}\text { Lappalainen and } \\
\text { Niskanen (2013) }\end{array}$ & Multiple & $\begin{array}{l}\text { Asymmetric information between } \\
\text { shareholders and bondholders, } \\
\text { retention of control }\end{array}$ & Both & $\mathrm{FB} / \mathrm{NFB}$ & Finland \\
\hline $\begin{array}{l}\text { Leitterstorf and Rau } \\
\text { (2014) }\end{array}$ & Equity & $\begin{array}{l}\text { Retention of control, protection of } \\
\text { reputation }\end{array}$ & Demand & $\mathrm{FB} / \mathrm{NFB}$ & Germany \\
\hline Lin and Chuang (2011) & Equity & $\begin{array}{l}\text { Asymmetric information between } \\
\text { shareholders }\end{array}$ & Supply & $\mathrm{FB} / \mathrm{NFB}$ & Taiwan \\
\hline $\begin{array}{l}\text { López-Gracia and } \\
\text { Sánchez-Andújar } \\
\text { (2007) }\end{array}$ & Debt & Financial distress costs & Both & $\mathrm{FB} / \mathrm{NFB}$ & Spain \\
\hline Mahérault (2004) & Equity & Retention of control & Supply & Within FB & France \\
\hline Marti et al. (2013) & Equity & $\begin{array}{l}\text { Asymmetric information between } \\
\text { shareholders }\end{array}$ & Both & FB/NFB & Spain \\
\hline $\begin{array}{l}\text { Martinez and Serve } \\
\text { (2011) }\end{array}$ & Equity & Aversion to risk & Demand & $\mathrm{FB} / \mathrm{NFB}$ & France \\
\hline Masulis et al. (2011) & $\begin{array}{l}\text { Retained } \\
\text { earnings }\end{array}$ & $\begin{array}{l}\text { Asymmetric information between } \\
\text { shareholders }\end{array}$ & Both & $\mathrm{FB} / \mathrm{NFB}$ & Multiple \\
\hline $\begin{array}{l}\text { Matias Gama \& } \\
\text { Manuel Mendes } \\
\text { Galvão (2012) }\end{array}$ & Debt & $\begin{array}{l}\text { Asymmetric information between } \\
\text { shareholders, retention of control, } \\
\text { aversion to risk }\end{array}$ & Demand & $\mathrm{FB} / \mathrm{NFB}$ & Portugal \\
\hline Maula et al. (2005) & Equity & NA & Supply & FB/NFB & Finland \\
\hline $\begin{array}{l}\text { Mazzola and Marchisio } \\
\text { (2002) }\end{array}$ & Equity & NA & NA & $\mathrm{FB} / \mathrm{NFB}$ & Italy \\
\hline McConaughy (1999) & Multiple & NA & NA & Both & NA \\
\hline $\begin{array}{l}\text { McConaughy, et al. } \\
\text { (2001) }\end{array}$ & Debt & Aversion to risk & Demand & $\mathrm{FB} / \mathrm{NFB}$ & US \\
\hline Michiels et al. (2015) & $\begin{array}{l}\text { Retained } \\
\text { earnings }\end{array}$ & $\begin{array}{l}\text { Asymmetric information between } \\
\text { shareholders }\end{array}$ & Demand & Within FB & Belgium \\
\hline $\begin{array}{l}\text { Mishra and } \\
\text { McConaughy (1999) }\end{array}$ & Debt & Aversion to risk & Demand & $\mathrm{FB} / \mathrm{NFB}$ & US \\
\hline Molly et al. (2010) & Debt & $\begin{array}{l}\text { Retention of control, aversion to } \\
\text { risk }\end{array}$ & Both & Within FB & Belgium \\
\hline Molly et al. (2012) & Debt & $\begin{array}{l}\text { Retention of control, aversion to } \\
\text { risk }\end{array}$ & Demand & Within FB & Belgium \\
\hline Muske et al. (2009) & Debt & NA & Demand & NA & US \\
\hline Napoli (2012) & Debt & $\begin{array}{l}\text { Asymmetric information between } \\
\text { shareholders and bondholders, } \\
\text { social capital }\end{array}$ & Supply & Within FB & Italy \\
\hline Nielsen (2008) & Equity & NA & Supply & $\mathrm{FB} / \mathrm{NFB}$ & NA \\
\hline Noordin et al. (2008) & Equity & NA & Supply & FB/NFB & Asia \\
\hline O'Regan et al. (2010) & Multiple & Retention of control & Demand & Within FB & UK \\
\hline Pindado et al. (2012) & $\begin{array}{l}\text { Retained } \\
\text { earnings }\end{array}$ & $\begin{array}{l}\text { Asymmetric information between } \\
\text { shareholders }\end{array}$ & Demand & $\mathrm{FB} / \mathrm{NFB}$ & EU \\
\hline Pindado et al. (2015) & Debt & $\begin{array}{l}\text { Asymmetric information between } \\
\text { shareholders and bondholders }\end{array}$ & Supply & Both & EU \\
\hline Poutziouris (2001) & Equity & Retention of control & Demand & FB/NFB & UK \\
\hline Poutziouris (2011) & Multiple & $\begin{array}{l}\text { Asymmetric information between } \\
\text { shareholders and bondholders, } \\
\text { retention of control }\end{array}$ & Both & $\mathrm{FB} / \mathrm{NFB}$ & UK \\
\hline $\begin{array}{l}\text { Psillaki and Eleftheriou } \\
\text { (2015) }\end{array}$ & Debt & $\begin{array}{l}\text { Asymmetric information between } \\
\text { lenders and borrowers }\end{array}$ & Supply & $\mathrm{FB} / \mathrm{NFB}$ & France \\
\hline Romano et al. (2001) & Multiple & $\begin{array}{l}\text { Retention of control, aversion of } \\
\text { risk, protection of reputation }\end{array}$ & Both & Within FB & Australia \\
\hline Santos et al. (2014) & Debt & $\begin{array}{l}\text { Free cash flow hypothesis, } \\
\text { retention of control, aversion to } \\
\text { risk }\end{array}$ & Both & $\mathrm{FB} / \mathrm{NFB}$ & EU \\
\hline
\end{tabular}




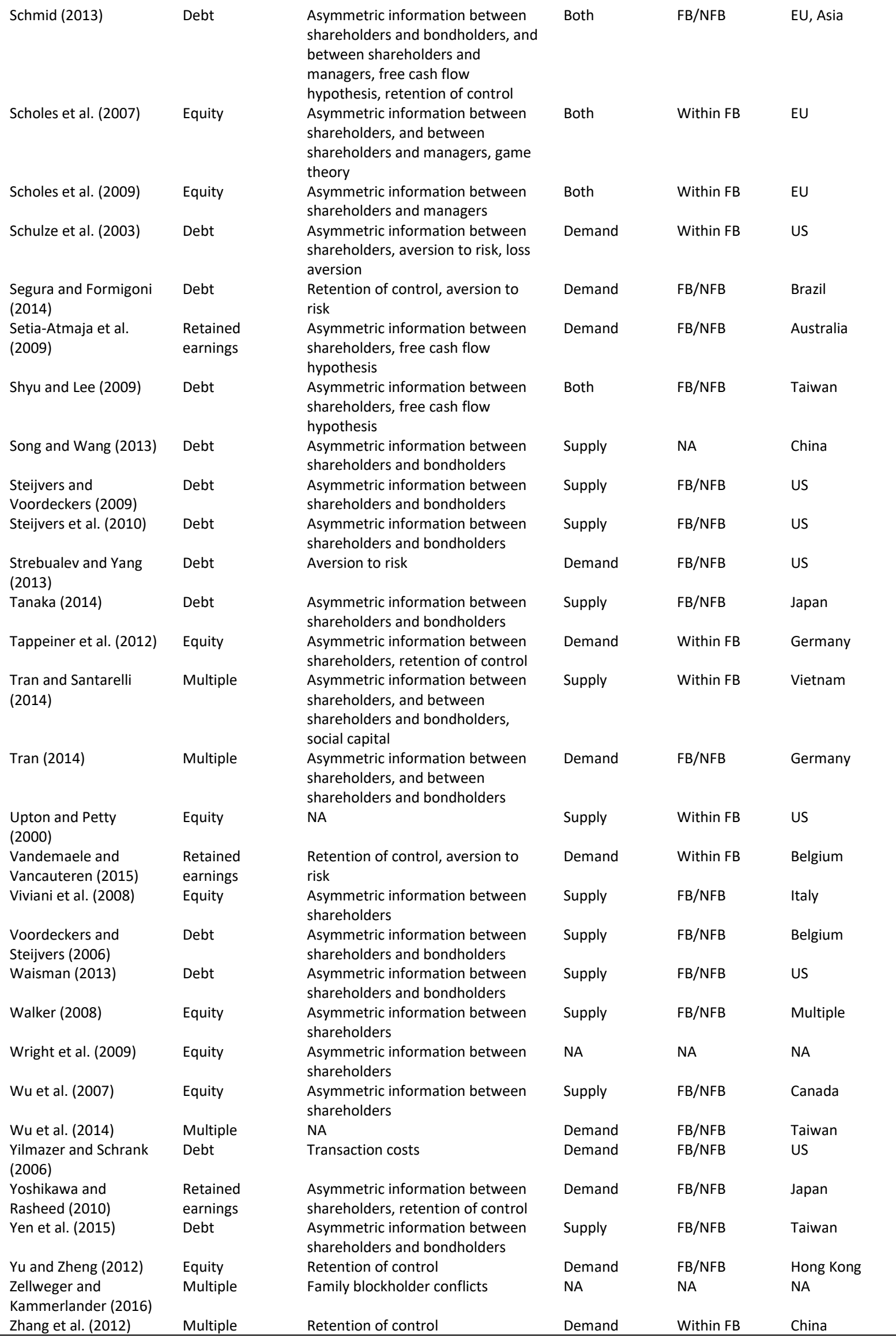

